\title{
Influence of openings, with and without confinement, on cyclic response of infilled R-C frames: an experimental study
}

Sigmund, Vladimir; Penava, Davorin

Source / Izvornik: Journal of Earthquake Engineering, 2014, 18, 113 - 146

Journal article, Published version

Rad u časopisu, Objavljena verzija rada (izdavačev PDF)

https://doi.org/10.1080/13632469.2013.817362

Permanent link / Trajna poveznica: https://urn.nsk.hr/urn:nbn:hr:133:227107

Rights / Prava: Attribution 4.0 International/Imenovanje 4.0 međunarodna

Download date / Datum preuzimanja: 2023-04-26

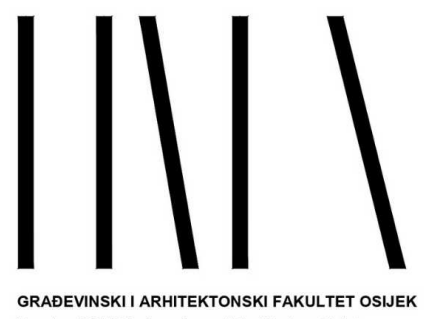

Repository / Repozitorij:

Repository GrAFOS - Repository of Faculty of Civil Engineering and Architecture Osijek
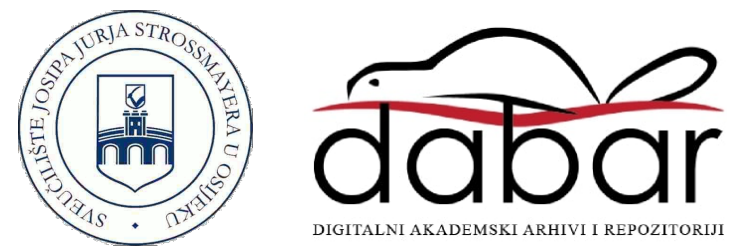


\section{Influence of Openings, With and Without Confinement, on Cyclic Response of Infilled R-C Frames - An Experimental Study}

\section{Sigmund \& D. Penava}

To cite this article: V. Sigmund \& D. Penava (2014) Influence of Openings, With and Without Confinement, on Cyclic Response of Infilled R-C Frames - An Experimental Study, Journal of Earthquake Engineering, 18:1, 113-146, DOI: 10.1080/13632469.2013.817362

To link to this article: https://doi.org/10.1080/13632469.2013.817362

Accepted author version posted online: 11

Jul 2013.

Published online: 11 Jul 2013.

Submit your article to this journal $\pi$

Џ Article views: 410

Q View related articles $\widetilde{ }$

View Crossmark data $\nearrow$

Citing articles: 9 View citing articles 


\title{
Influence of Openings, With and Without Confinement, on Cyclic Response of Infilled R-C Frames - An Experimental Study
}

\author{
V. SIGMUND and D. PENAVA \\ Faculty of Civil Engineering Osijek, Josip Juraj Strossmayer University of Osijek, \\ Osijek, Croatia
}

\begin{abstract}
This article presents the experimental results of a study on reinforced-concrete frames infilled with masonry with openings. The frames were designed according to current European codes. They were built in a scale 1:2.5 and infilled with masonry walls. Mid-size window and door openings were located centrically and eccentrically and were executed with and without tie-columns around them. Presence of masonry infill, although not accounted for in design, improved the system behavior (increase in stiffness, strength and energy dissipation capacity) at drift levels of up to 1\%. During the test, openings did not influence the initial stiffness and strength at low drift levels. Their presence became noticeable at higher drift levels, when they lowered the energy dissipation capacity of the system. The infill wall had a multiple failure mechanism that depended on the opening height and position. Tie-columns controlled the failure type, independent of the opening type, prevented out-of-plane failure of the infill, and increased the system's ductility. Negative effects of the infill on the frame were not observed. The infill's contribution could be deemed positive as it enhanced the overall Structural Performance Level. Analytical expressions commonly used for infilled frames underestimate the infill's contribution to strength and stiffness and overestimate the contribution of the bare frame.
\end{abstract}

Keywords Infilled R-C Frames; Masonry Infill; Opening Type and Position; Confinement; Quasistatic Cyclic Loading; Analytical Verification

\section{Introduction}

Reinforced-concrete (R-C) frames infilled with masonry walls, with- or without openings, are a common architectural element in low- and medium-height buildings. The infill walls stiffen the frame and reduce the first-mode period, leading to a reduction of drift response to strong ground motion. At the same time, the addition of masonry wall within the frame tends to increase the base-shear response and reduce the drift capacity of the structure. The increase of shear force and reduction of drift capacity leads to serious vulnerabilities unless proper proportioning is exercised. The specific flaws in unintentional frame-wall systems were identified in the aftermath of the Skopje earthquake of 1963. These were: (1) weaknesses introduced by openings in the wall, (2) captive columns, (3) out-of-plane collapse of walls, and (4) column failures under reversals of combinations of shear and tensile or compressive forces. These flaws have continued to cause tragic consequences in subsequent urban earthquakes [Aschheim, 2000; Sezen et al., 2003]. The most recent examples occurred in profusion in Wenchuan [2008] and L'Aquila [2009].

Received 22 December 2011; accepted 16 June 2013.

Address correspondence to D. Penava, Faculty of Civil Engineering Osijek, Josip Juraj Strossmayer University of Osijek, Osijek, Croatia. E-mail: dpenava@gfos.hr 
A review of the literature shows that consensus on the effects of the interaction between frames and masonry walls is lacking. Some researchers have suggested that infill walls have led to collapse of buildings [Aschheim, 2000; Sezen et al., 2003; Kyriakides and Billington, 2008] and that infill walls may affect the response of frames detrimentally [Murty, 2006]. Some others have suggested that masonry infill panels may be beneficial [Akin, 2006; Hassan and Sozen, 1997; Fardis and Panagiotakos, 1997; Henderson et al., 2002; Mehrabi and Shing, 1997]. The contradictions in the views of the research community have led to the deconstruction of the frame-wall system in many regional building codes, which contain warnings about the interaction of frames and walls but mostly fail to provide recommendations and bounds on their proper proportioning, as in EN 1998-1 [2004].

An equivalent strut model with overcrossing diagonals, which substitute the masonry infill [Stafford-Smith, 1966], is usually used for numerical modelling of the "framed-wall" system. This simple and intuitive solution requires knowledge of the infill's potential failure mechanism [FEMA 306, 1998]. The suggested diagonal's strut width varies in different studies [Kalman and Sigmund, 2008] and is not the same for different drifts [Crisafulli, 1997]. The presence of openings in the wall is particularly problematic, as they interrupt the continuity of diagonals and change the wall's failure mechanism. This problem is recognized by the guidelines [FEMA 273, 1997; FEMA 274, 1997; FEMA 306, 1998; FEMA 356,2000 ], which recommend consideration of the infill as a set of sub-components. Their application, however, is difficult.

An approach based on the failure of individual masonry zones was suggested by Kakaletsis and Karayannis [2007, 2008, 2009]. The disadvantage of this approach is that it based on a case-by-case methodology, i.e., it is bounded by information on the failure mechanisms gained in a limited number of experiments. According to the above studies, the size and shape of the opening did not significantly affect the load capacity and stiffness, but their position had more influence on the observed behavior.

In this article, we tried to clear some of the uncertainties regarding the behavior of the framed-wall system with openings under lateral loading. The influence of different opening types, dimensions and positions in the wall was experimentally determined using one-bay, one-story specimens with medium-sized opening. The contribution of vertical tie-columns around the opening was also investigated. The specimens were tested under constant vertical and quasi-static cyclic lateral load until the infill's failure.

Reinforced-concrete frames with masonry infill had higher stiffness, strength, and energy dissipation capacity than bare frames. Presence of opening changed the failure mechanism, causing cracking of the infill at an early stage and decreasing the energy dissipation capacity. The infill with opening showed pronounced bed-joint sliding that led to separation of infill into sub-components. Vertical ties around the opening controlled the failure mechanism, enhanced drift capacity of the infill panel and prevented its out-of-plane collapse during the in-plane tests. Obtained ductility and behavior factors were better than suggested for confined masonry. The possibility of fully exploiting the masonry infill in design of new buildings and retrofit of old ones should be exploited.

\section{Test Specimens}

Ten specimens of one-story, one-bay, reinforced concrete frames with equal dimensions, material properties, and reinforcement, were produced at a scale of 1:2.5. The frame represented the middle bay of a three-bay frame (bay widths $6 \mathrm{~m}, 5 \mathrm{~m}, 6 \mathrm{~m}$ ) and a base frame of a seven-story frame (story heights $3.70 \mathrm{~m}$ and $6.0 \times 3.0 \mathrm{~m}$ ) building and was designed according to the guidelines [EN 1992-1-1, 2004; EN 1998-1, 2004] as medium-ductility 
frame (DCM). The contribution of the infill wall was neglected during design. Prototype details were taken from [Zovkic et al., 2012].

The cross-sections of reinforced-concrete frame elements were $b_{c} \times d_{c}=20.0 \times$ $20.0 \mathrm{~cm}$ for the columns and $\mathrm{b}_{\mathrm{b}} \times \mathrm{d}_{\mathrm{b}}=12.0 \times 20.0 \mathrm{~cm}$ for the beam. The masonry infill wall was $t_{i}=12.0 \mathrm{~cm}$ thick with the aspect ratio $l_{i} / h_{i}=1.4$. The opening in the masonry wall represented a window or door opening type. The window aspect ratio was $l_{0} / h_{o}=$ $50.0 / 60.0 \mathrm{~cm}=0.83$ with the opening area $\mathrm{A}_{\mathrm{o}}=0.30 \mathrm{~m}^{2}$, with parapet wall $\mathrm{P}=40.0 \mathrm{~cm}$ high. The door aspect ratio was $1_{\mathrm{o}} / \mathrm{h}_{\mathrm{o}}=35.0 / 90.0 \mathrm{~cm}=0.39$ with the opening area $\mathrm{A}_{\mathrm{o}}=$ $0.32 \mathrm{~m}^{2}$.

The specimens are presented in Table 1. Specimens in Group I had the door and window opening located either at the middle or at the edge. Specimens in Group II also had vertical reinforced-concrete ties $\left(b_{s} \times d_{s}=12.0 \times 6.0 \mathrm{~cm}\right)$ around the opening. They extended from the foundation beam to the beam and were anchored in these. Specimens in Group III were bare and fully infilled reinforced-concrete frame.

The frame elements were reinforced with ribbed reinforcing bars (longitudinal reinforcement $\varnothing 10 \mathrm{~mm}$ for columns and $\varnothing 10 \mathrm{~mm}$ and $\varnothing 6 \mathrm{~mm}$ for beams). Stirrups in columns with $\varnothing 6 \mathrm{~mm}$ were placed at an interval of 7.5 and $15 \mathrm{~cm}$ and in beams $\varnothing 6 \mathrm{~mm}$ placed at intervals of 10 and $20 \mathrm{~cm}$. Reinforcement details are shown in Fig. 1.

Vertical ties were reinforced with two longitudinal reinforcement bars, each of $\varnothing 8 \mathrm{~mm}$. These were anchored into the beams by dowels nailed $10 \mathrm{~cm}$ into previously drilled holes. Dowel stirrups, $\varnothing 4 \mathrm{~mm}$, were anchored into every second horizontal mortar joint. Reinforcing details are presented in Fig. 2. The lintel above the opening was reinforced by four longitudinal bars of $\varnothing 6 \mathrm{~mm}$ with stirrups of $\varnothing 6 \mathrm{~mm}$ placed at intervals of $9 \mathrm{~cm}$.

Compressive strength of the concrete was determined on concrete cubes $(15.0 / 15.0 / 15.0 \mathrm{~cm})$ in compliance with [EN 12390-3, 2009] and the obtained values are given in Table 2. The masonry infill wall was made with hollow-clay units (high vertical strength / low horizontal strength) with dimensions $1_{\mathrm{u}} / \mathrm{w}_{\mathrm{u}} / \mathrm{h}_{\mathrm{u}}=25 / 12 / 9.5 \mathrm{~cm}$, belonging to Group IIb according to [EN 771-1, 2003; EN 772-16:2000/A1, 2004; EN 772-3, 1998; EN $772-13,2000]$. The masonry units were cut from the original ones, preserving the number and area of holes (with almost the same percentage of voids) with the nominal unit strength of $\mathrm{f}_{\mathrm{b}}=10 \mathrm{MPa}$, normalized compressive strength $\mathrm{f}_{\mathrm{b}}=15.9 \mathrm{~N} / \mathrm{mm}^{2}$ in vertical and $\mathrm{f}_{\mathrm{bh}}=$ $2.6 \mathrm{~N} / \mathrm{mm}^{2}$ in the horizontal direction [EN 772-1, 2000]. There were an equal number of wall bed joints in the prototype and the specimens. Cement-lime general purpose mortar was produced in situ with a volume ratio of lime:cement:sand $=1: 1: 5$, a compressive strength $\mathrm{f}_{\mathrm{m}}=5.02 \mathrm{~N} / \mathrm{mm}^{2}$ and tensile strength $\mathrm{f}_{\mathrm{mt}}=1.27 \mathrm{~N} / \mathrm{mm}^{2}$ [EN 1015-11:1999/A1, 2006]. Masonry mortar joints were $1 \mathrm{~cm}$ thick with fully mortared head joints. Detailed material properties were found in [Matošević et al., 2006; Penava et al., 2011].

In additional tests, in accordance with [EN 1052-1, 1998], the characteristic compressive strength of masonry wallets was measured in the vertical direction, $\mathrm{f}_{\mathrm{k}}=$ $2.7 \mathrm{~N} / \mathrm{mm}^{2}(\mathrm{~V}=5.5 \%)$, with corresponding modulus of elasticity, $\mathrm{E}=3900 \mathrm{~N} / \mathrm{mm}^{2}$. The characteristic value of the initial shear strength was $\mathrm{f}_{\mathrm{vk} 0}=0.35 \mathrm{~N} / \mathrm{mm}^{2}$ with internal friction coefficient $\tan \alpha_{\mathrm{k}}=0.24$ [EN 1052-3, 2002]. Reinforcing bars were of type B500B with characteristic yield strength $\mathrm{f}_{\mathrm{yk}}=594 \mathrm{~N} / \mathrm{mm}^{2}$, ultimate strength $\mathrm{f}_{\mathrm{uk}}=699 \mathrm{~N} / \mathrm{mm}^{2}$ and modulus of elasticity $\mathrm{E}=206957 \mathrm{~N} / \mathrm{mm}^{2}$.

\subsection{Test Procedure and Equipment}

The test setup consisted of a closed steel testing frame connected to the strong floor. Lateral deformations of the resisting frame were prevented by braces, as shown in Fig. 3. The frame was stiff enough to prevent any interaction with the forced response of the specimen being tested. 


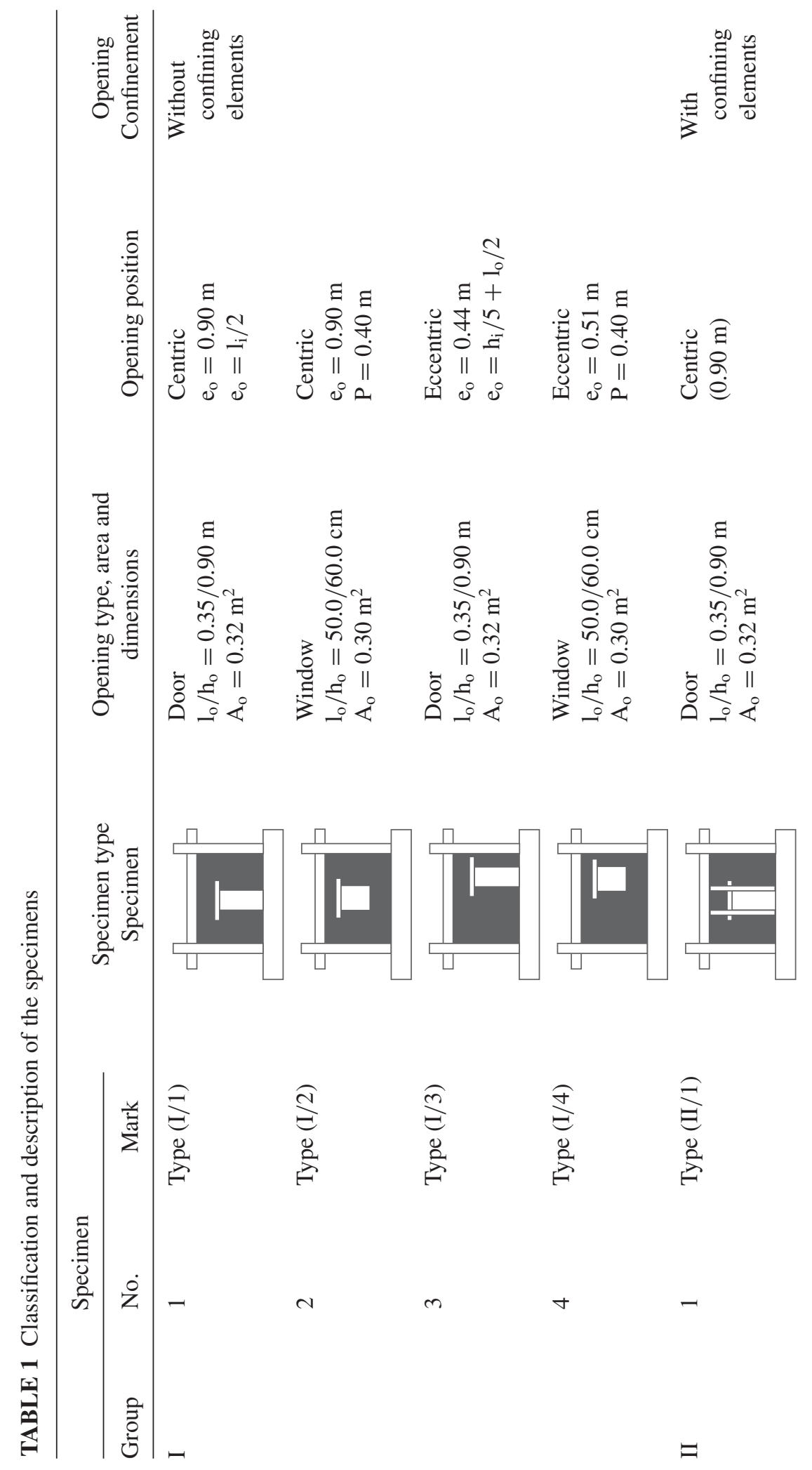




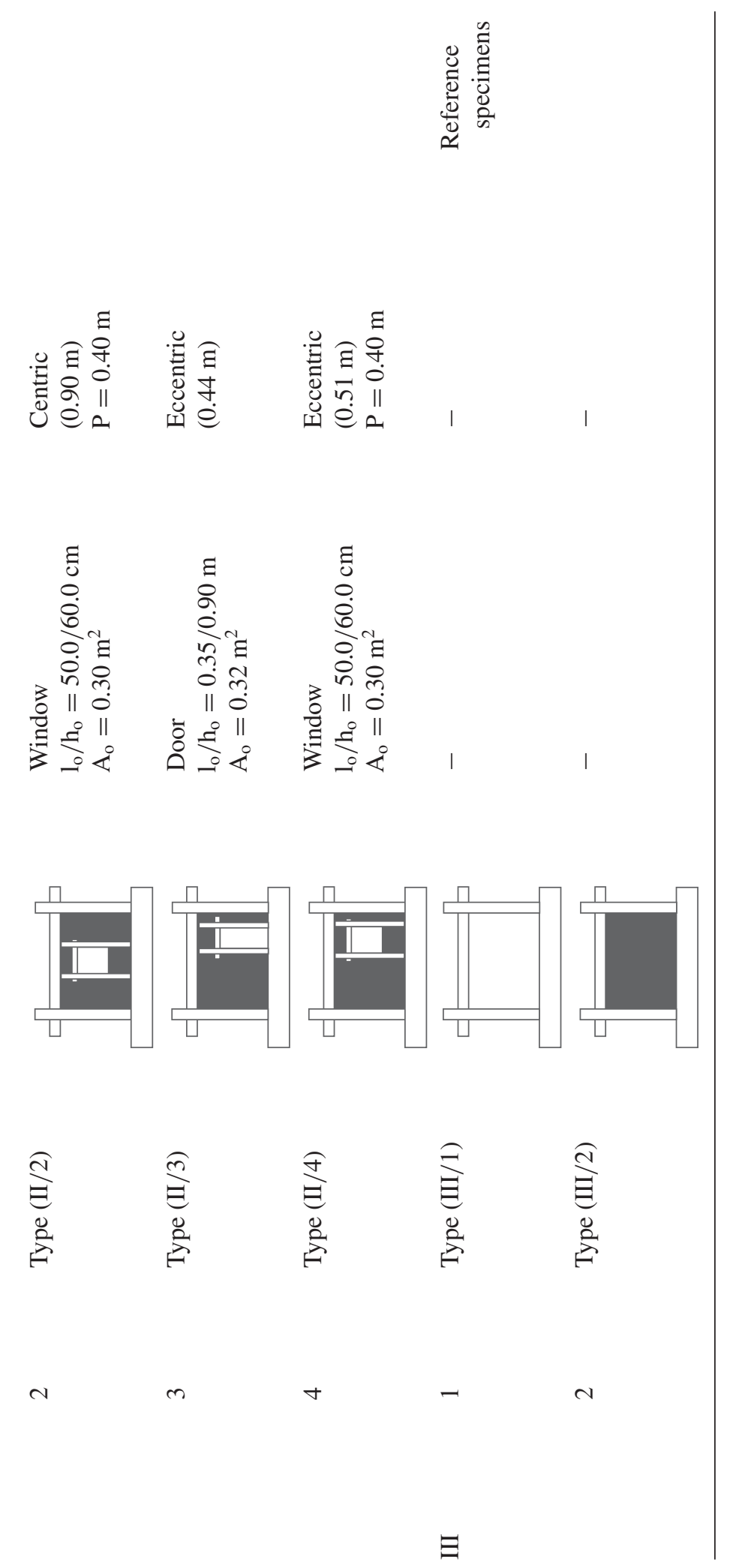



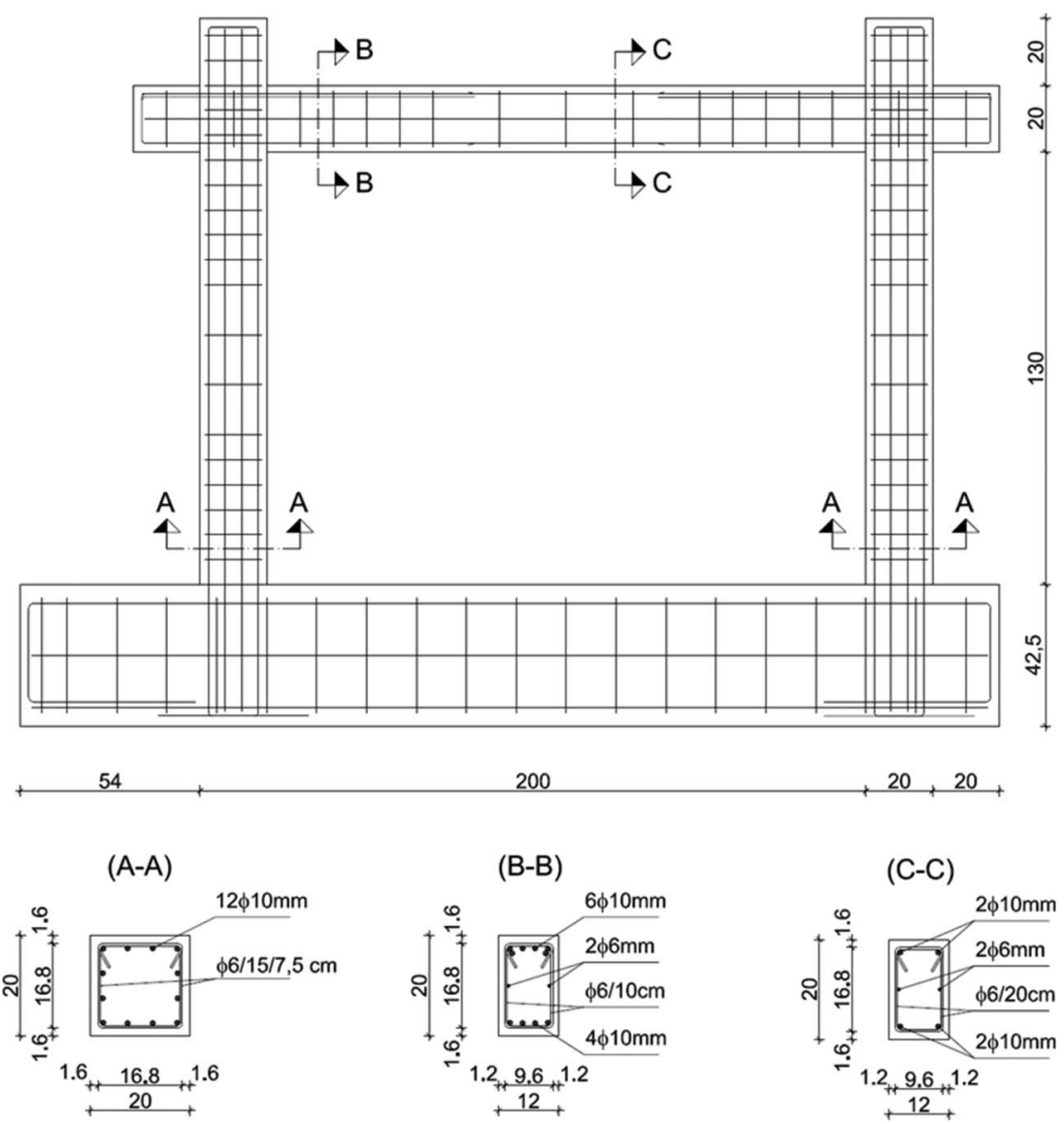

FIGURE 1 Reinforcement details and specimen's dimensions (cm).
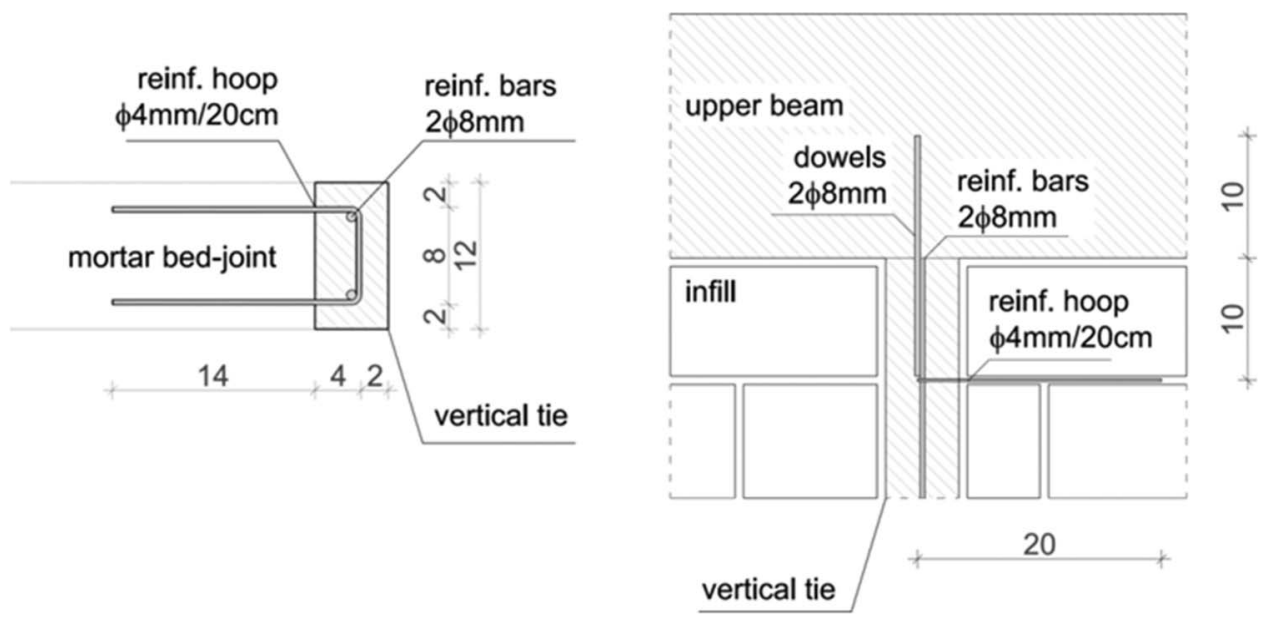

FIGURE 2 Tie-reinforcement details in the cross-section (left) and in elevation (right). 


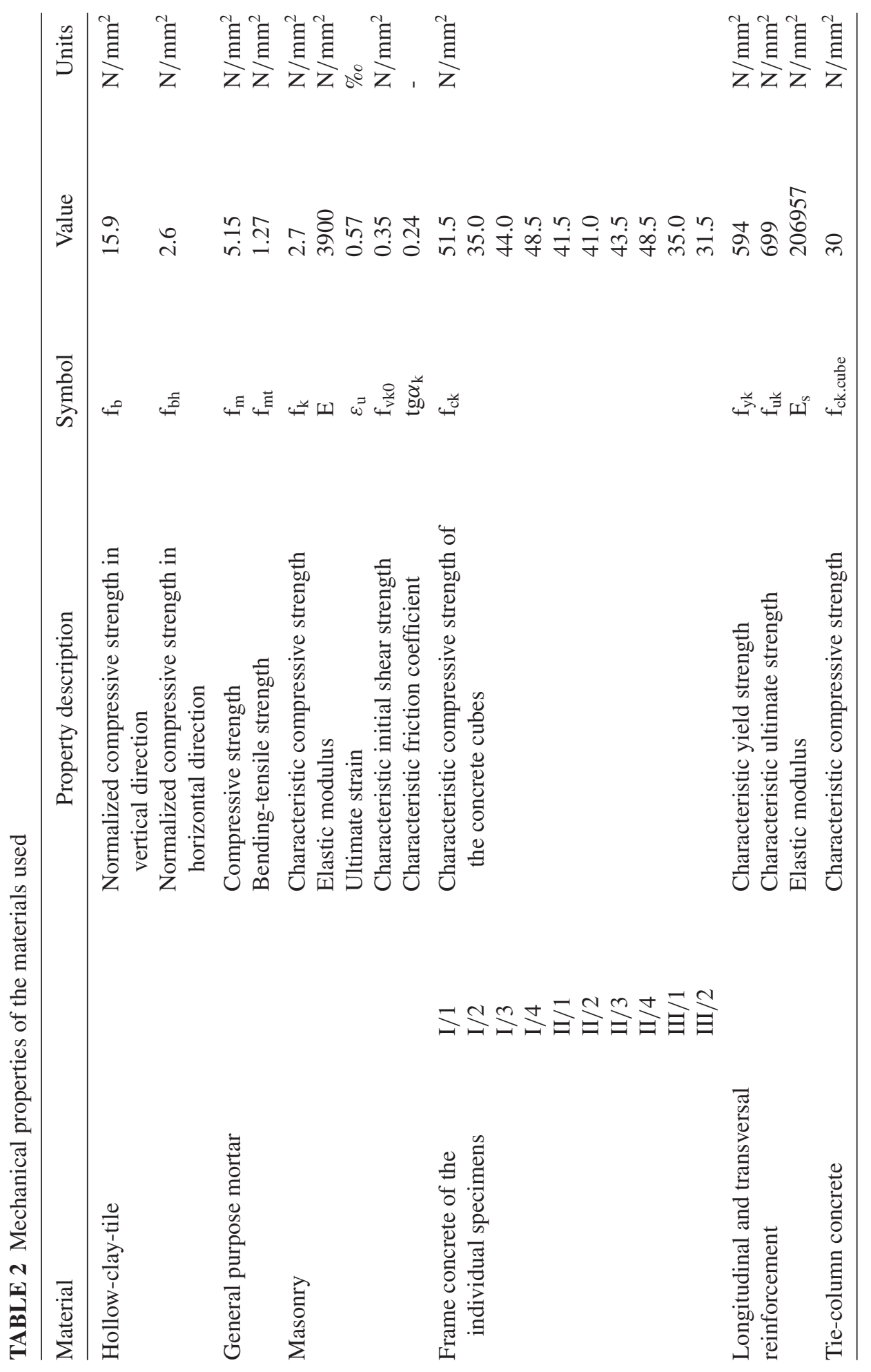




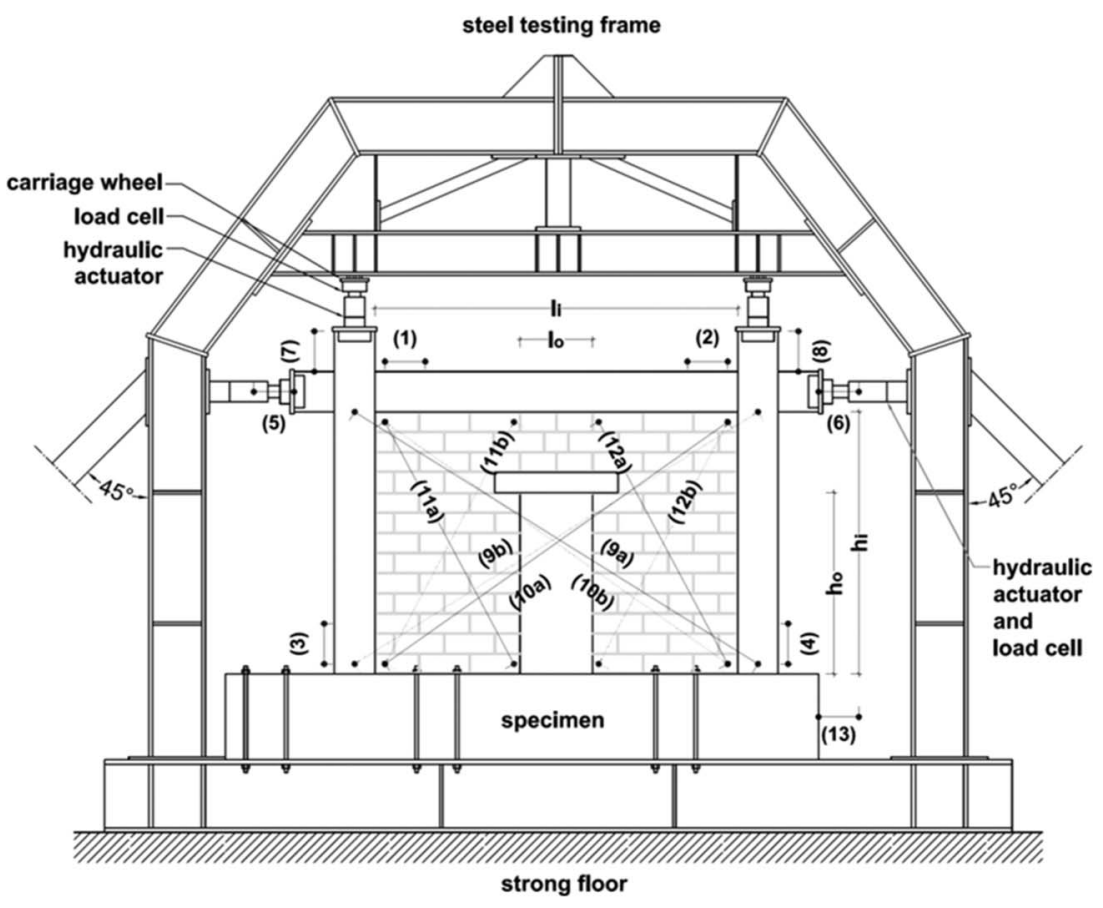

FIGURE 3 Test setup.

The specimen's foundation beam was fixed to the steel frame and the floor. Four hydraulic actuators were fixed to the frame in order to simulate constant vertical and quasistatic lateral loadings. Vertical load, simulating loading from the upper floors, was applied to the specimen's columns' tops by means of two vertical hydraulic actuators of $500 \mathrm{kN}$ capacity and $+150 \mathrm{~mm}$ stroke. The load was kept constant at $\mathrm{N}=365 \mathrm{kN}$ by means of the pressure valves mounted on the actuators. Vertical hydraulic actuators were placed on carriage wheels that enabled the horizontal column's displacement and prevented its rotation. Two hydraulic actuators, of $350 \mathrm{kN}$ capacity and stroke $\pm 150 \mathrm{~mm}$, were fixed to the frame at beam level in order to simulate the cyclic in plane lateral load. It was applied quasi-statically and cyclically, first as force (at the initial stage up to yielding) and then as displacement controlled (after yielding), according to [FEMA 461, 2007]. The load was increased stepwise in a series of increments of $10 \mathrm{kN}$, repeating each step twice, until the structural system yielded. Then displacements were increased by increments of $1 \mathrm{~mm}$ until the drift of 1.0-1.2\% was reached, or the masonry wall came out of plane. When the masonry infill wall was extensively damaged, lateral loading was applied from one side only, up to the infill's total failure. Recorded loading history is presented in Fig. 4.

Extensive instrumentation was utilized to monitor all aspects of the specimens' behavior. A schematic depiction of the instruments' location is shown in Fig. 3. The test measured applied forces by pressure transducers, lateral displacements on the left (5) and right end of the R-C beam (6) and vertical displacements (7 and 8) using LVDTs mounted on separate scaffolding. Diagonal deformations were measured by string transducers on the frame $(9 \mathrm{a}$ and $9 \mathrm{~b}$ ) and on the masonry infill (10a and 10b) on the front (a) and back (b) side of the specimen. Specimens with openings were additionally provided with diagonal string transducers on one (11a and 11b) and/or other side of the opening (12a and 12b) depending on the opening's type and position. Measuring devices, 12a and 12b were not placed in the case of eccentric opening. Local strains were measured by strain gauges at the column's bottom and at the beam's hinge location (1-4). For signal conditioning, data acquisition 


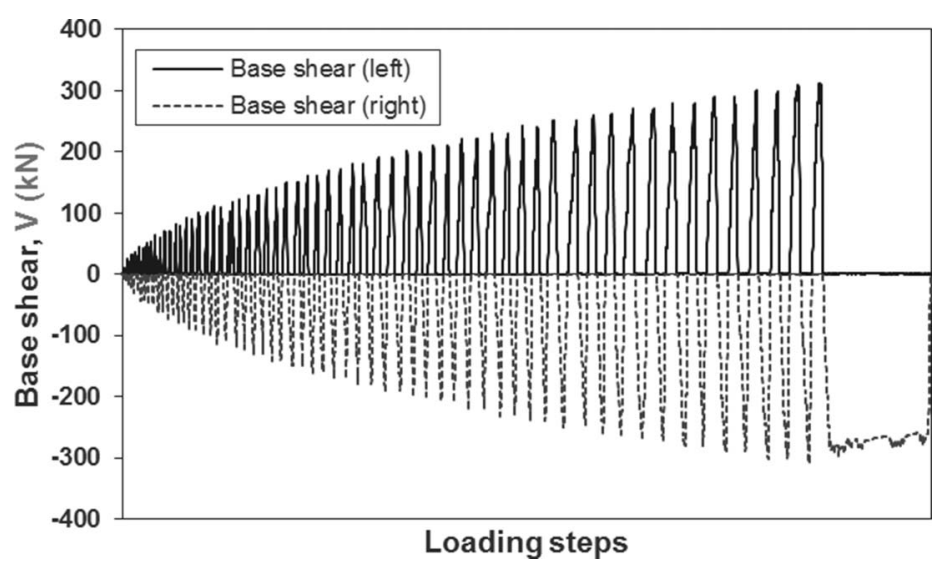

FIGURE 4 Recorded loading history.

and analysis, two Dewe30-16 systems with software DEWEsoft ver.6.6.7. [DEWESoft v.6.6.7, 2010; DEWE-BOOK, 2010] were used. Formation of the cracks in masonry wall and all other significant phenomena that occurred during testing were optically observed, registered, measured and photographed.

\subsection{Test Results}

The presented results describe failure sequence and type, experimental response curves (hysteresis loops), resistance envelope curves (primary curves), secant lateral stiffness, and hysteretic damping at various drifts.

\section{Failure Type and Sequence}

The infill failure mechanism could be described by three basic modes: (a) bending, (b) shear (diagonal), and (c) bed-joint sliding shear failure. These were manifested by corner crushing, diagonal tensile cracks and bed-joint sliding, respectively. The presence of the opening caused the infill's division into sub-components, namely vertical masonry piers and horizontal masonry spandrels, and this was observed in all tests. Stress-concentration occurred at the opening's corners, resulting in increased damage to the infill. There were no significant bending or shear cracks on the frame elements. The final crack patterns of the specimens are presented in Figs. 5-8 and are described in detail in the following section, with the main data presented in Table 3.

\subsection{Specimens in Group I}

Diagonal tensile cracks occurred in the masonry piers at an angle of $45-65^{\circ}$ (Figs. 6ad). At higher drifts they became unstable and tended to fall out of the plane. Pier height was equal to that of the opening. Diagonal shear and/or horizontal bed-joint sliding shear failure of the pier were dominant.

\subsection{Specimens in Group II}

Introduction of the vertical tie-columns influenced the infill's behavior during the test. Diagonal tensile cracks occurred in masonry piers at an angle of $45-65^{\circ}$ (Figs. 7a-d). The 
a) Type (I/1)

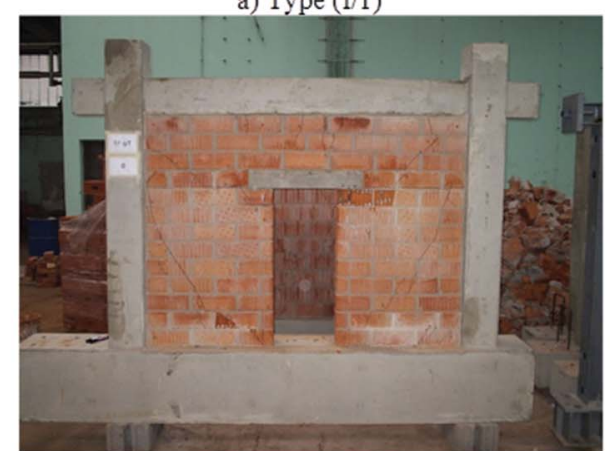

c) Type (I/3)

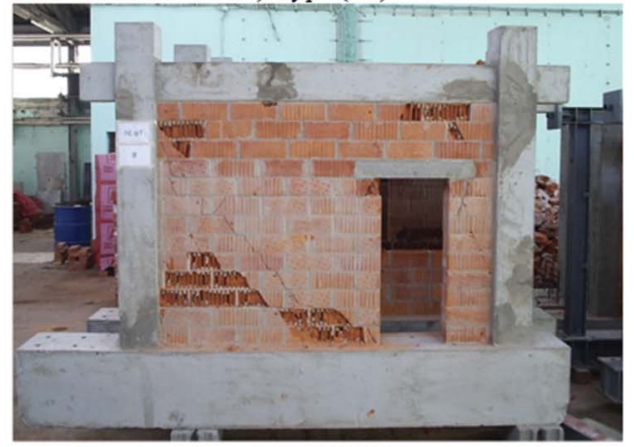

e) Type (II/1)

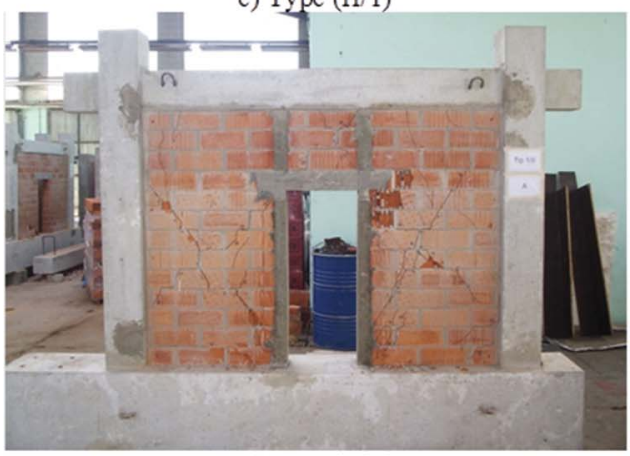

g) Type (II/3)

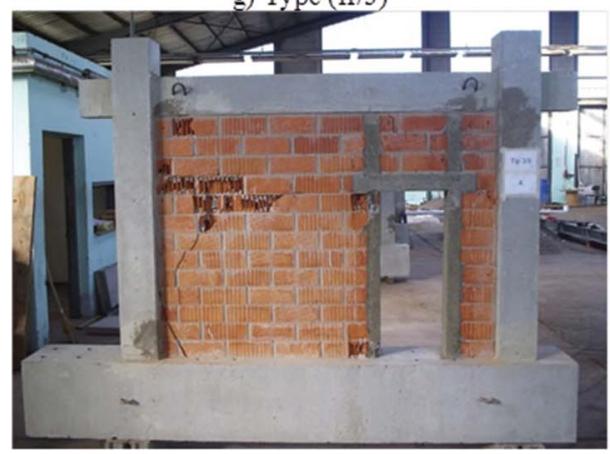

b) Type (I/2)

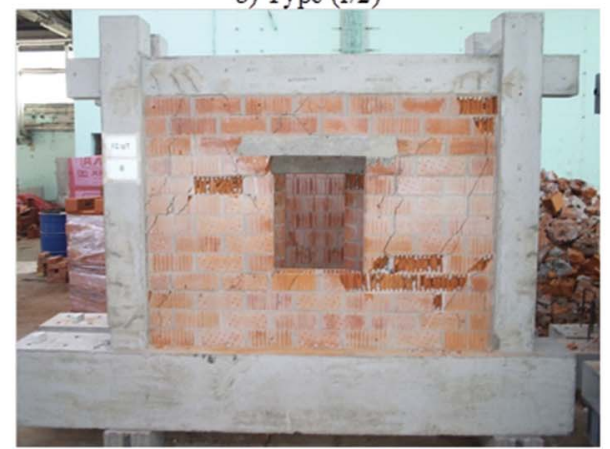

d) Type (I/4)

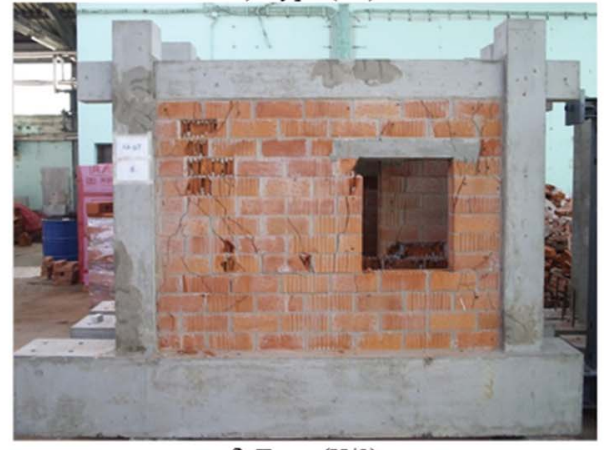

f) Type (II/2)

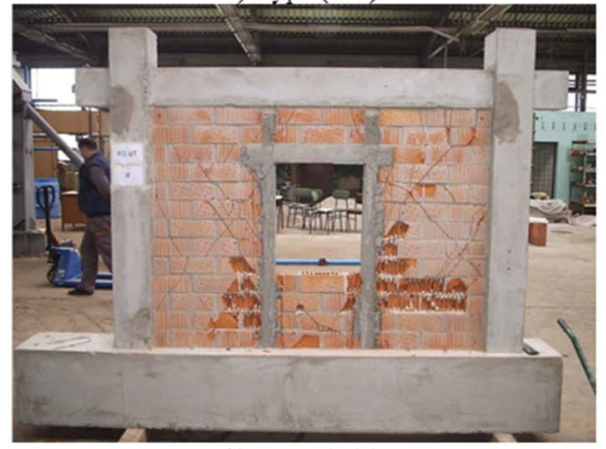

h) Type (II/4)

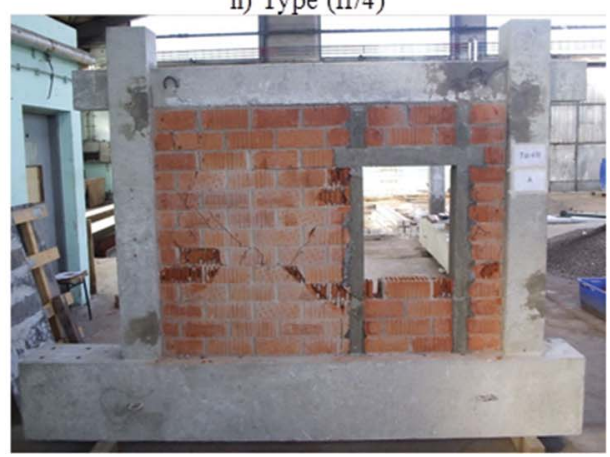

FIGURE 5 Specimens after the test (color figure available online). 

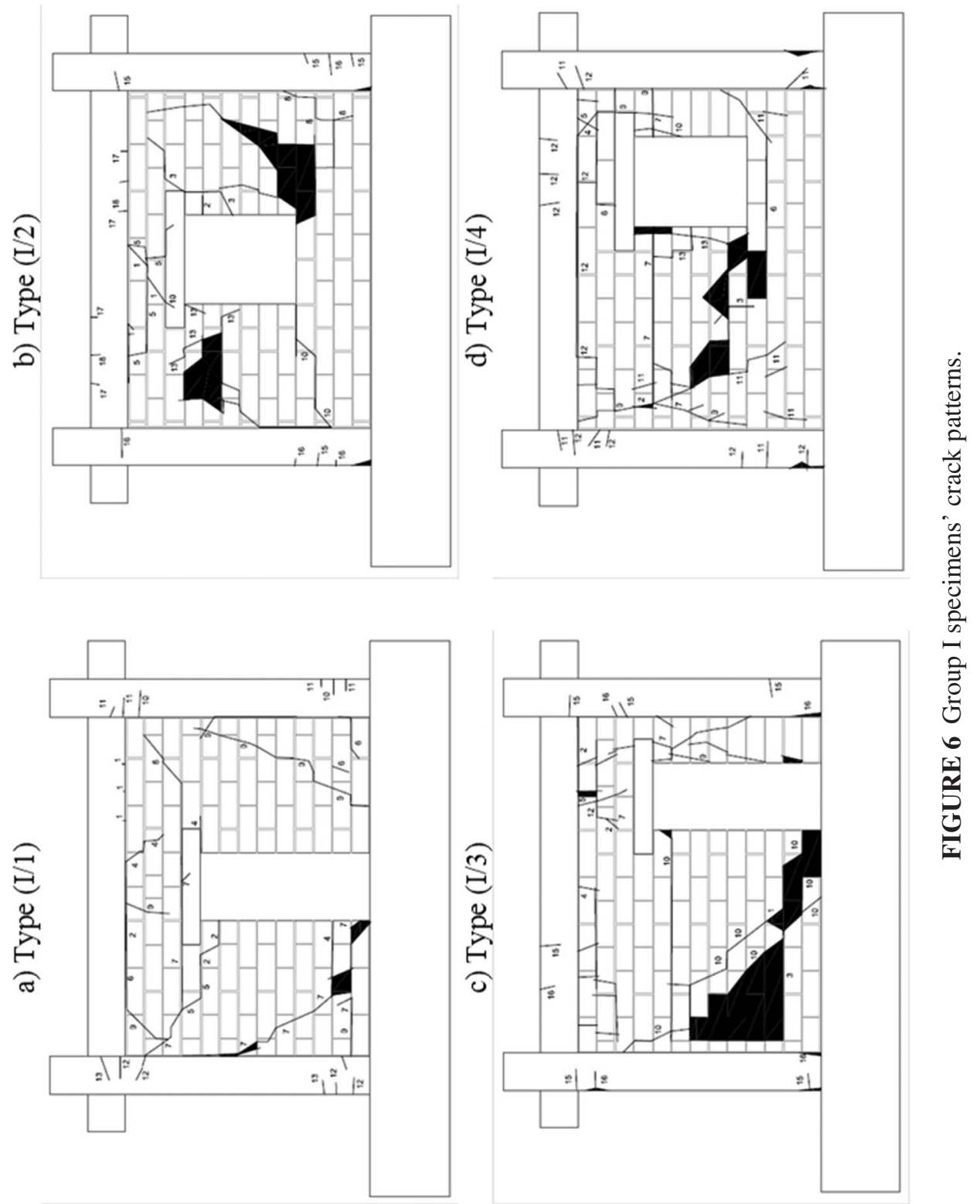

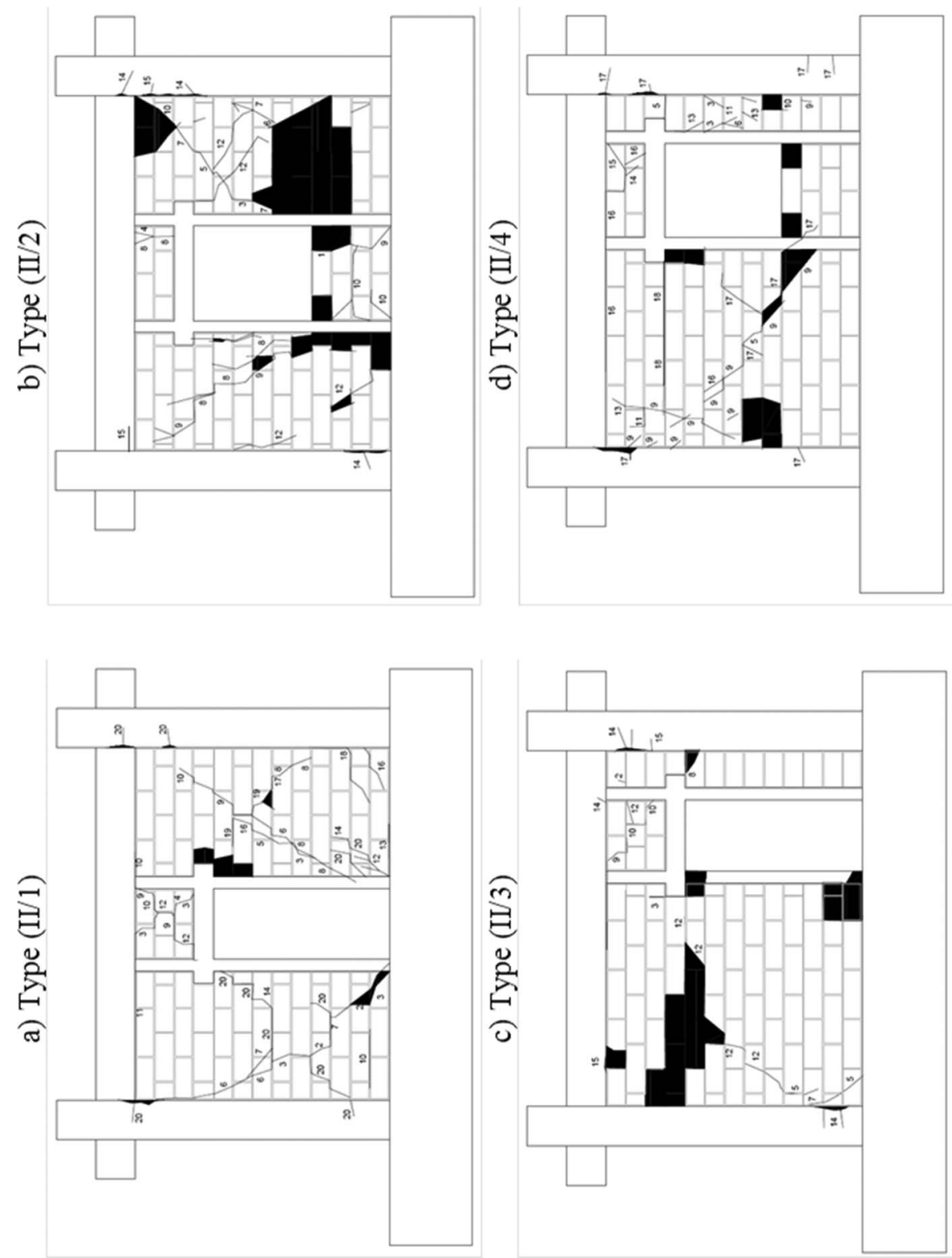

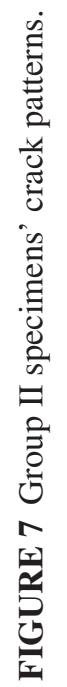




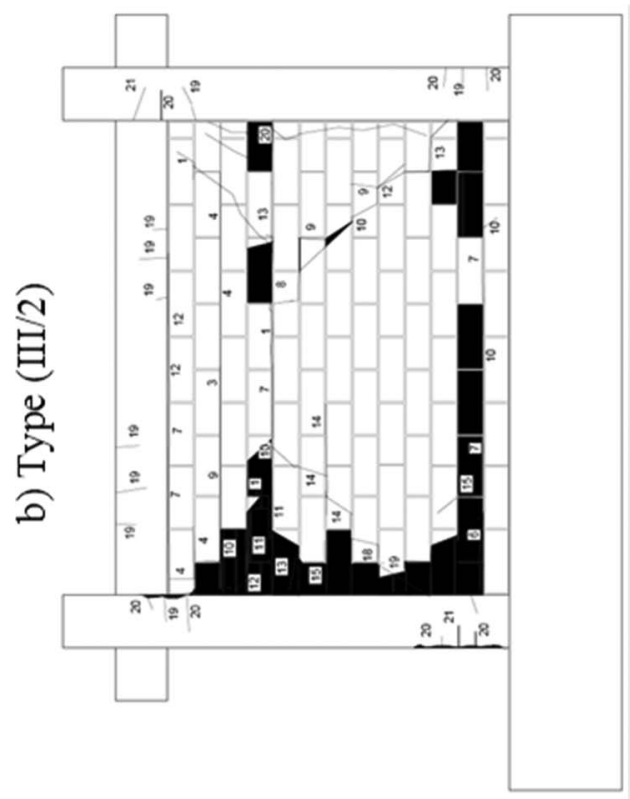

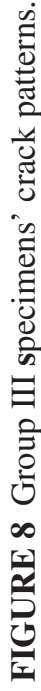




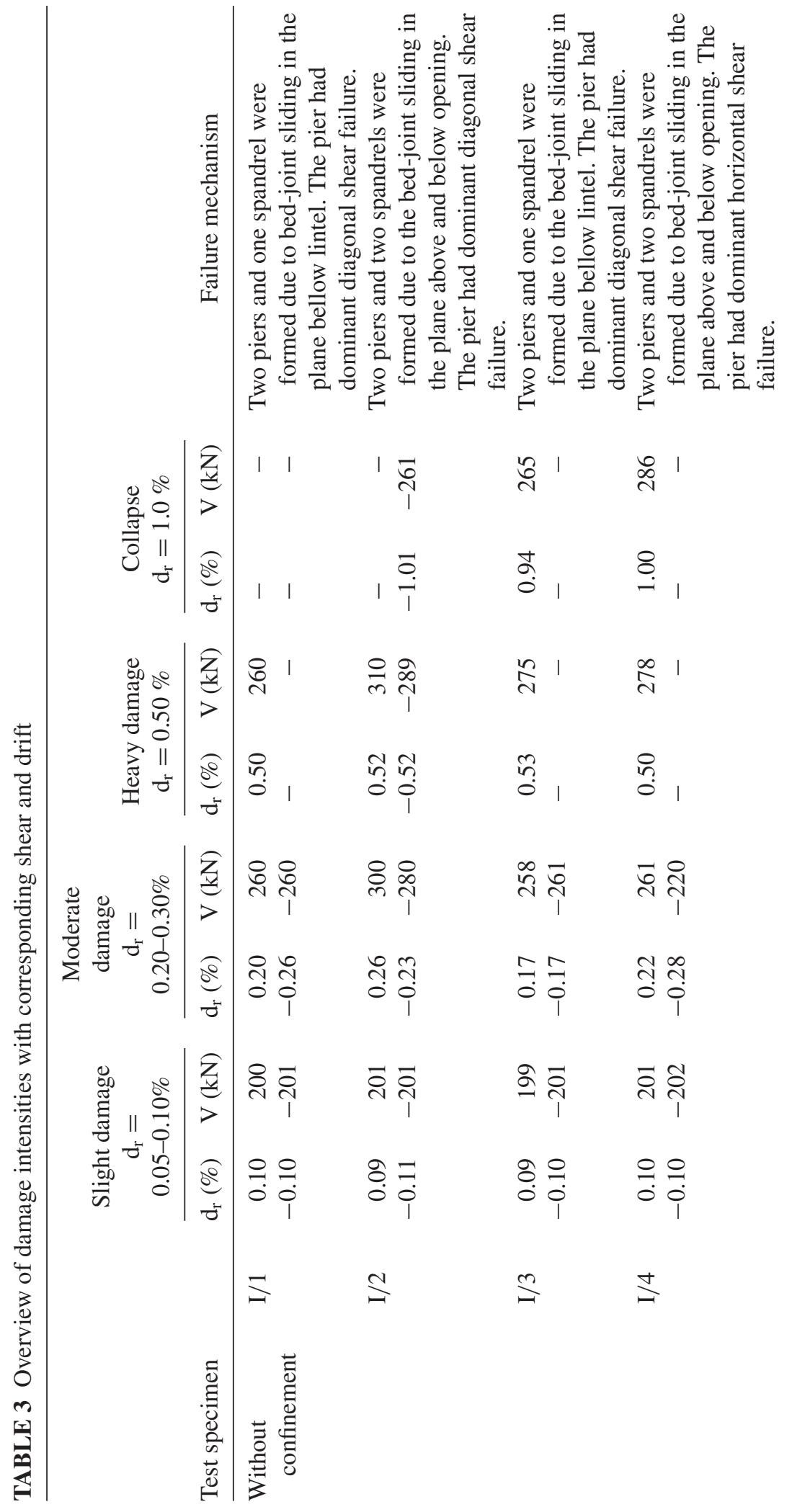




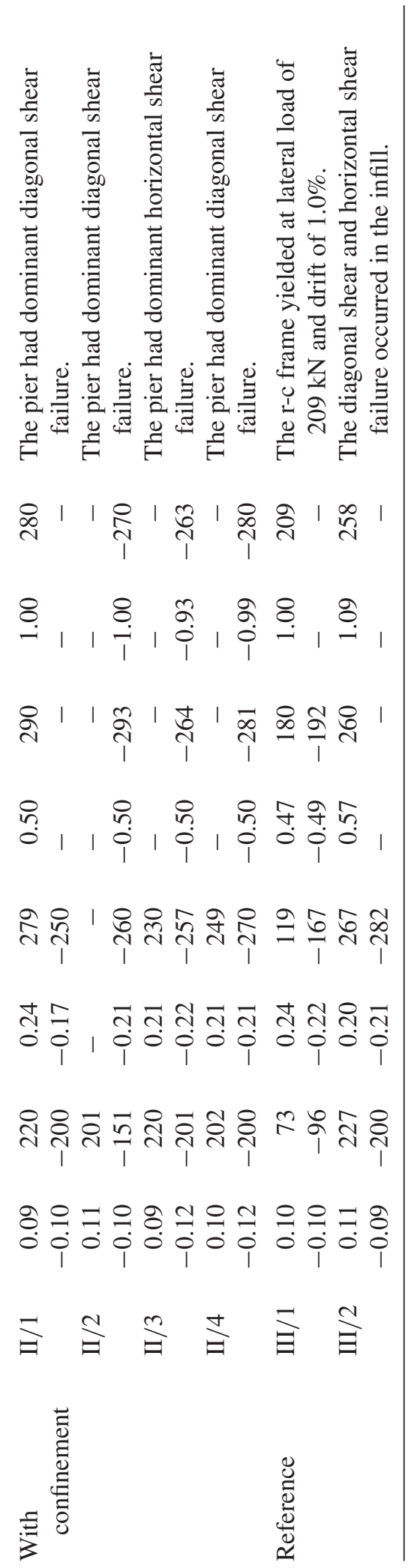


height of the opening did not influence the pier's height and in the most cases it was equal to the infill's height (except in the case when the tie failed in shear). The cracks that crossed tie elements were observed on the specimens with eccentrically placed openings, on the side of the infill's bigger pier. They were close to the opening's edges. Dominant were diagonal shear and/or horizontal bed-joint sliding shear failures of the pier.

\subsection{Specimen $(I I I / 1)$}

The reinforced-concrete frame yielded at a lateral displacement of $\pm 14.00 \mathrm{~mm}\left(\mathrm{drift}_{\mathrm{r}}=\right.$ $1.00 \%$ ) and horizontal load of $209 \mathrm{kN}$. Plastic hinges were formed at columns' bottoms and beam's ends. After-yield stiffness was about $5 \%$ of the initial value. The frame structure was able to carry the vertical load up to drifts of $2 \%$ without degradation. Strong column-weak beam flexural failure was dominant, and the observed crack pattern is shown in Fig. 8a.

\subsection{Specimen $(I I I / 2)$}

The infill wall collapsed at lateral displacement $\pm 15.24 \mathrm{~mm}\left(\mathrm{~d}_{\mathrm{r}}=1.09 \%\right)$ and horizontal load $254 \mathrm{kN}$. Diagonal tension cracks extended from the corners and bed-joint sliding occurred in the mid plane of the masonry infill. At the infill-column interface significant crushing of the masonry units occurred (Fig. 8b) and horizontal shear failure was dominant.

Observed damage on the masonry infill was described according to the damage classification guide given in [FEMA 306, 1998]. Reinforced-concrete frame elements had insignificant (slight) damage. The overall results, drift $\left(\mathrm{d}_{\mathrm{r}}\right)$, base shear $(\mathrm{V})$, and dominant failure mechanisms, are presented in Table 3.

It was observed that inclined cracks tended to form at an angle of $45^{\circ}$, when geometry allowed, in all tested specimens. Stress concentrations around the opening caused extensive damage to the masonry infill, irrespective of the tie-columns presence. Masonry infill failed in shear in all tested specimens, with or without tie columns. Presence of the tie-columns prevented early loss of the in-plane stability (out-of-plane failure), increased ductility and diminished stiffness degradation of the system.

\section{Hysteretic Behavior and Lateral Strength}

Measured hysteretic loops and respective resistance envelope curves obtained for each specimen are presented in terms of base shear (V) vs. displacement (d) on the primary axes and shear stress $\left(V / A_{e}\right)$ vs. story $\operatorname{drift}\left(d_{r}\right)$ on the secondary axes. The equivalent cross section area $\left(A_{e}\right)$ of the infilled frame was calculated using the expression [Žarnić, 1992] as

$$
A_{e}=A_{m}+2 C_{E} A_{f} \frac{G_{f}}{G_{i}}
$$

where $A_{m}$ - cross-section of the masonry infill, $C_{E}$ - coefficient of the frame column influence towards the infill's stiffness $\left(C_{E}=1\right), A_{f}-$ cross-section of the column, $G_{f}$ and $G_{i}-$ shear modulus of the concrete $\left(G_{f}=15453 \mathrm{~N} / \mathrm{mm}^{2}\right)$, and masonry $\left(G_{i}=1560 \mathrm{~N} / \mathrm{mm}^{2}\right)$, respectively.

Hysteretic loops (obtained from the second loading cycle) and the primary curves are presented in Figs. 9-11. The primary curves were obtained by connecting the peaks of these cycles (solid part) and extending further (dashed part) when the specimen was pushed from one (weak) side only (pushover). It should be noted that the difference between the 

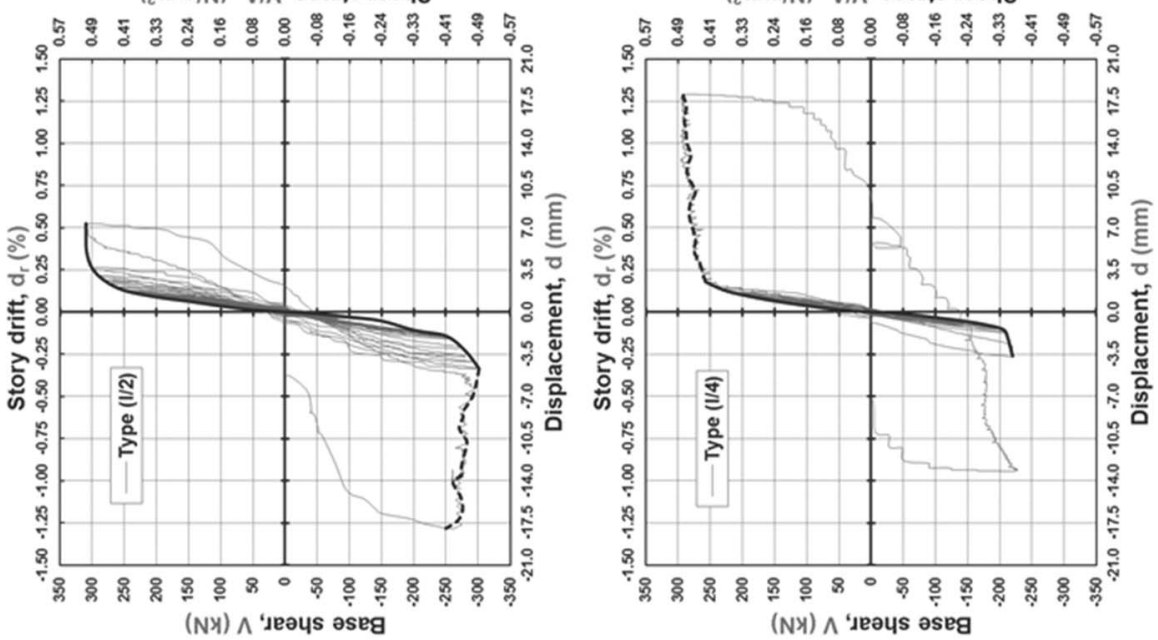

(

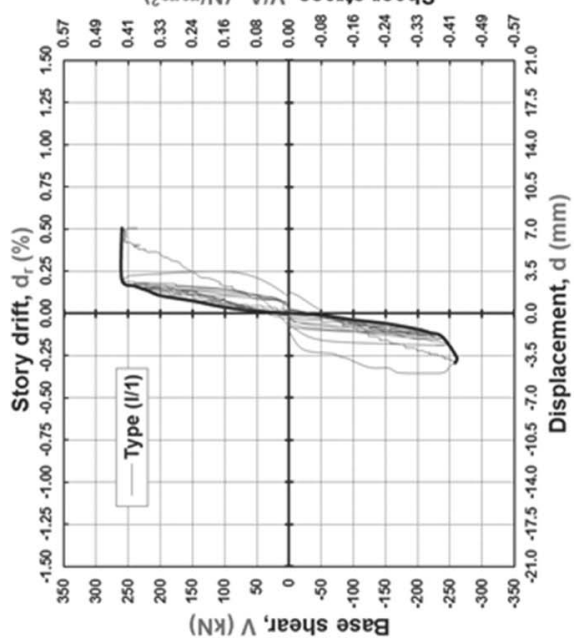

$\left({ }_{2} \mathrm{mu} / \mathrm{N}\right){ }^{\circ} \mathrm{VI \Lambda}$ 'ssonis neaus

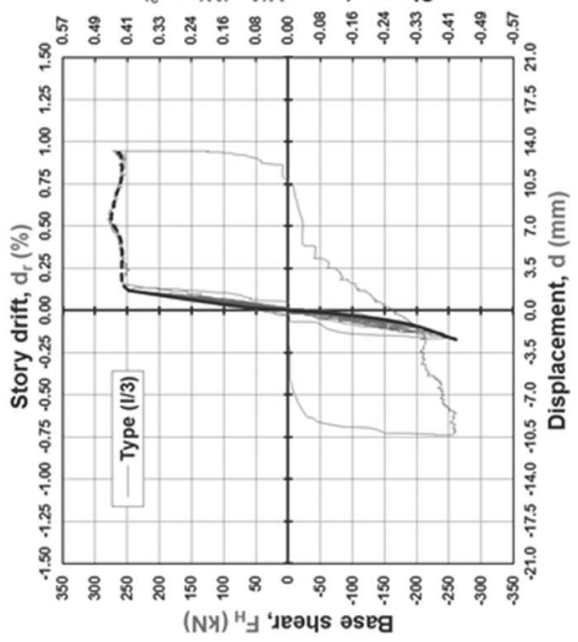

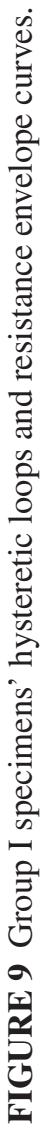




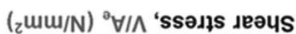

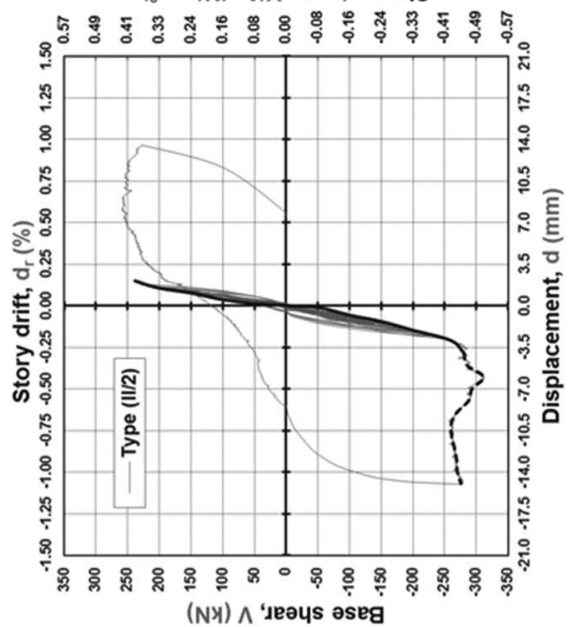

( ${ }^{2}$ mu/N/N) ${ }^{\circ} \mathrm{VI \Lambda}$ 'ssedis Jeəus

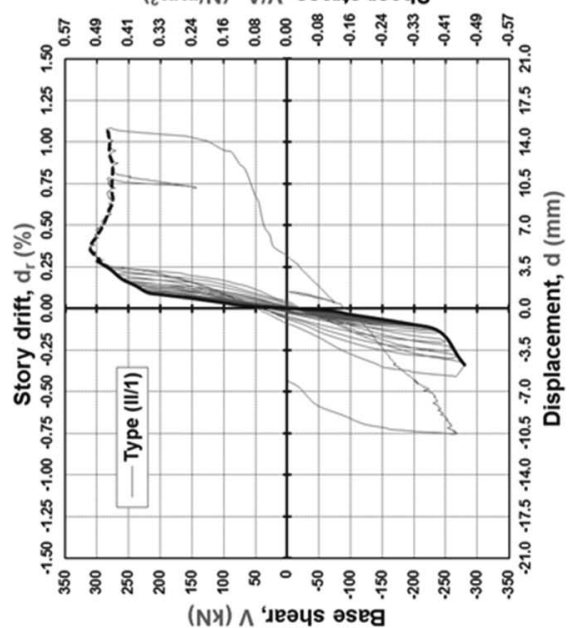

(

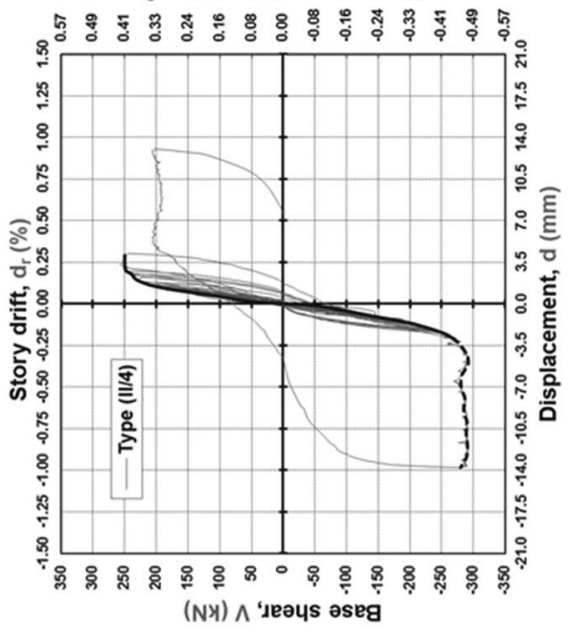

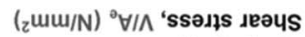

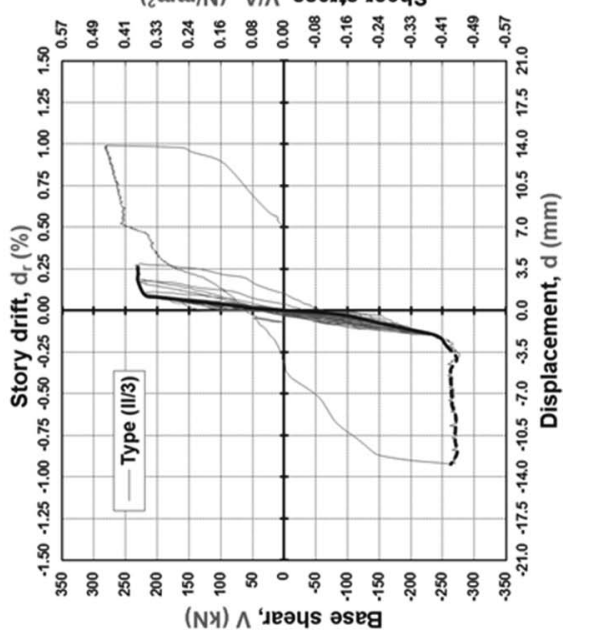




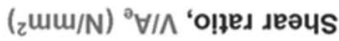

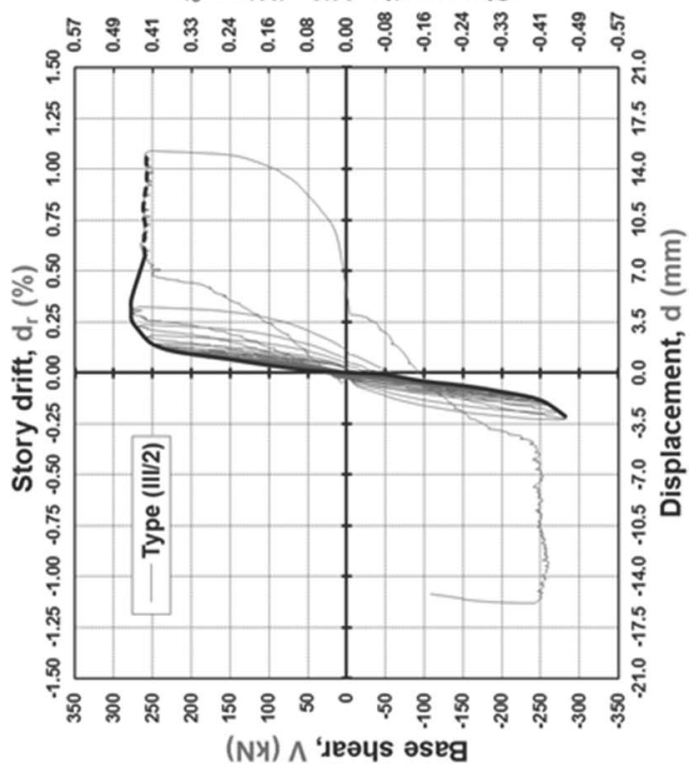

( $\left.{ }^{m} \mathrm{mu} / \mathrm{N}\right){ }^{\circ} \mathrm{V} / \mathrm{\Lambda}$ 'ssedps deaus

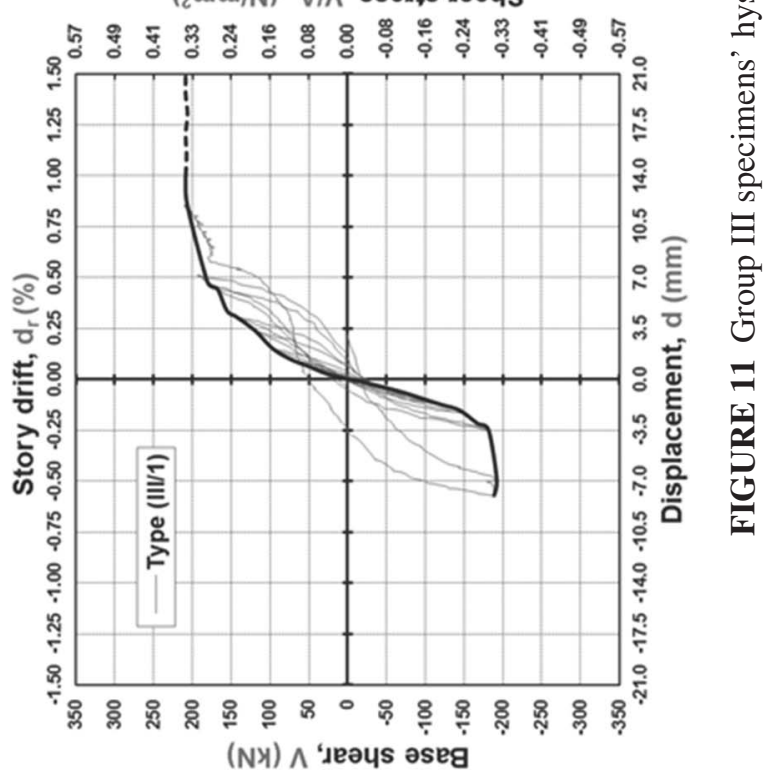


resistance envelope curves of the first and second cycles was negligible. The second cycles were chosen for connecting with the pushover part and for more reliable representation of the infill's current damage state.

The behavior of masonry infilled specimens was linear-elastic up to the slight damage level (story drift range $0.05-0.10 \%$ ). Then the stiffness decreased and lateral resistance increased. At the moderate damage level (story drift range $0.20-0.30 \%$ ) the specimens reached lateral load capacity and maintained it, or showed a slight increase of lateral resistance up to drifts of $0.50 \%$. Degradation started then and the lateral load capacity reached that of the bare frame at drifts of about $1.0 \%$. Measured results, obtained from the primary curves, are presented in Tables 3 and 4.

The infilled reinforced-concrete frame acted as a composite structural system ("framed-wall") up to the drifts of $0.50 \%$. The infill's presence was noticeable until it suffered heavy damage at drifts of about $0.75-1.0 \%$. Even after that point, its resistance was about 1.25 times higher than that of the bare frame.

Four behavior modes of the composite framed-wall were observed, and categorised according to the infill's damage: slight at drifts of $0.05-0.10 \%$, moderate at drifts of 0.20 $0.30 \%$, heavy at drifts of $0.50 \%$ and close to collapse at drifts of $0.75-1.0 \%$. Initial stiffness of all "framed-wall" specimens, with and without opening, was about three times higher than that of the bare frame structure, irrespective of the opening's type and position.

\section{Secant Lateral Stiffness}

Measured values of the secant stiffnesses $(\mathrm{K})$ for various drifts are given in Table 5 . The ratios of $\mathrm{K} / \mathrm{K}_{0}$, where $\mathrm{K}_{0}$ represents the initial secant stiffness, are also presented. Degradation (changes) of the specimens' secant stiffness in respect to drift is shown in Fig. 12.

The contribution of the masonry infill to the overall "framed-wall" stiffness decreased with increasing drifts and was about 2.8 times at moderate, 1.5 times at heavy, and negligible at pre-collapse damage levels. Secant stiffnesses of the infilled specimens were similar within the observed drifts. They decreased exponentially and were approximately $50 \%$ of the initial value at slight, $30 \%$ at moderate, $15 \%$ at heavy, and 5\% at close to collapse drift levels. Infills with the tie columns had higher stiffness at the same drifts and decreased more slowly. The contribution of tie columns became noticeable at increased drifts and was $14 \%$ at heavy and $56 \%$ at close to collapse drift levels.

\section{Energy Dissipation}

Energy dissipation $\mathrm{E}(\mathrm{kNmm})$ was calculated as the sum of areas inside hysteresis loops up to a certain drift level. Calculated values and the ratio of the system's dissipated energy versus that of the bare frame (III/1) are given in Table 6 and in Fig. 13a. Dissipated hysteretic energy, at Slight and Moderate damage levels, of infilled specimens was between 5 and 20 times higher than that of the bare frame. The ratio decreased at heavy damage and collapse drifts to about twice as high.

The system's inelastic response could be calculated by using an elastic SDOF system with reduced stiffness $\mathrm{EI}=\frac{\mathrm{EI}_{\mathrm{cr}}}{\mu}$ and increased damping as obtained from $\xi=0.2 \times$ $\left(1 \frac{1}{\sqrt{\mu}}\right)+0.02$ [Gulkan and Sozen, 1974]. Calculated equivalent damping values are presented in Table 7 and in Fig. 13b. It is obvious that addition of an infill, with or without opening, increased the equivalent damping values at small drifts, thus absorbing the input energy. At small drifts the equivalent damping of the framed-wall was about four times higher and at higher drifts about 1.5 times higher than that of the bare frame. 


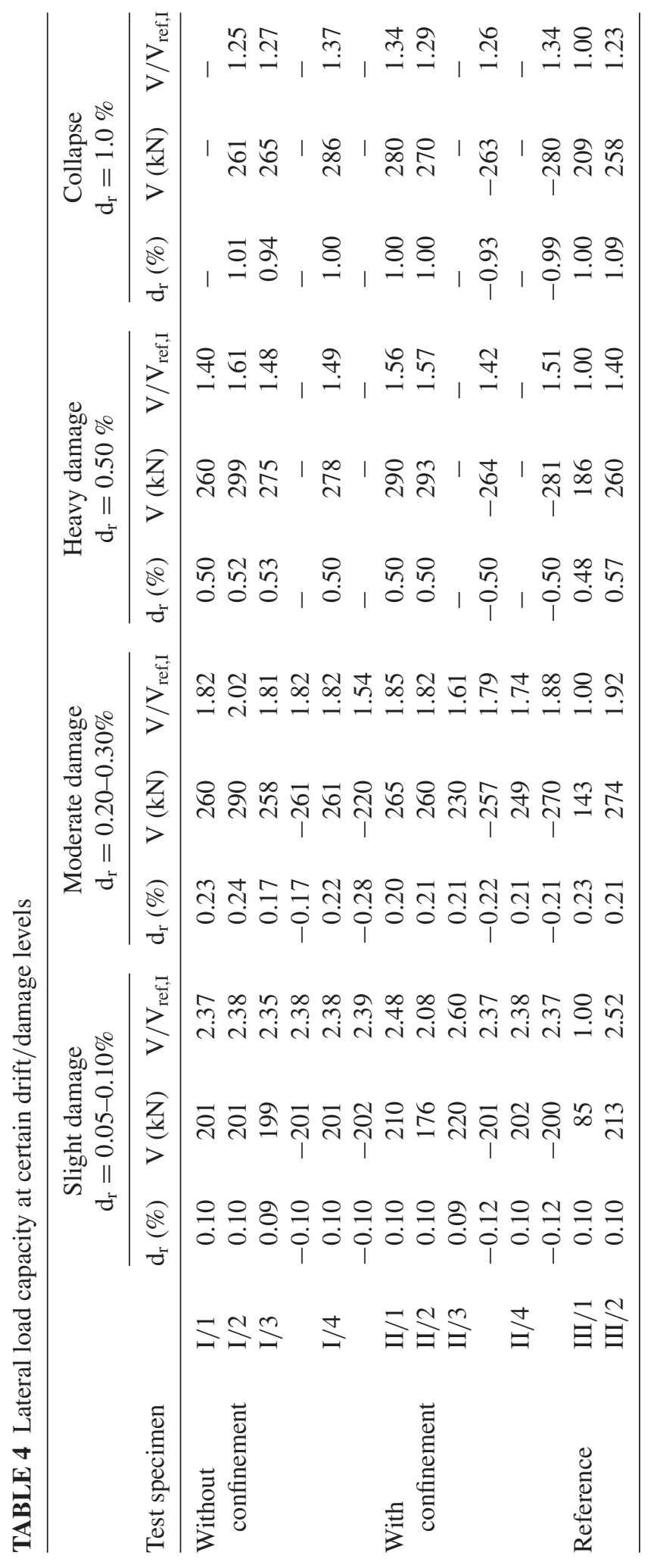




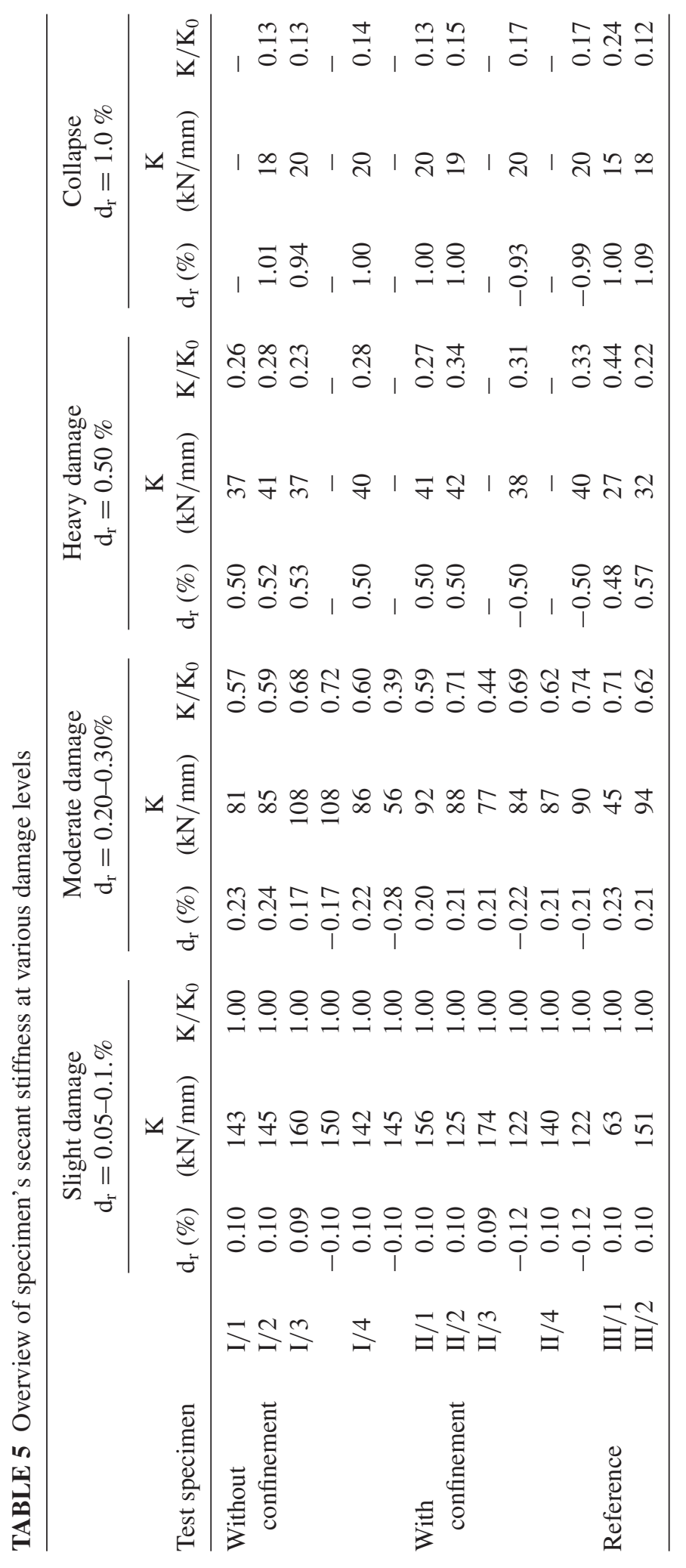




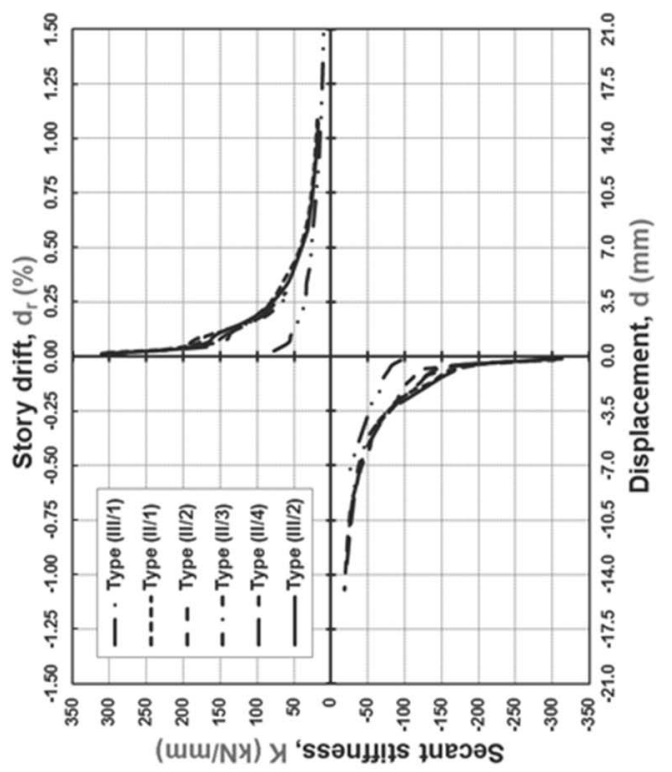

|

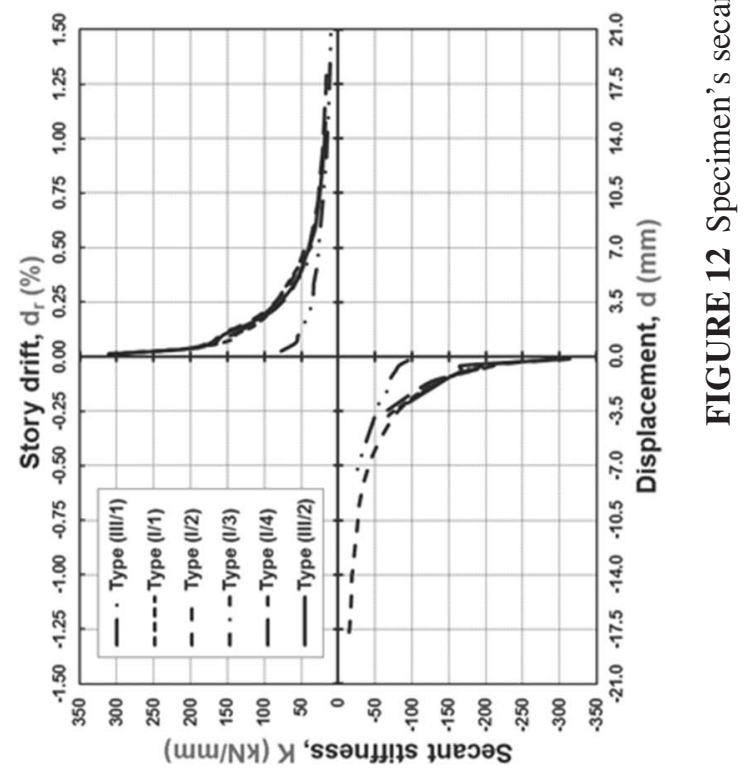




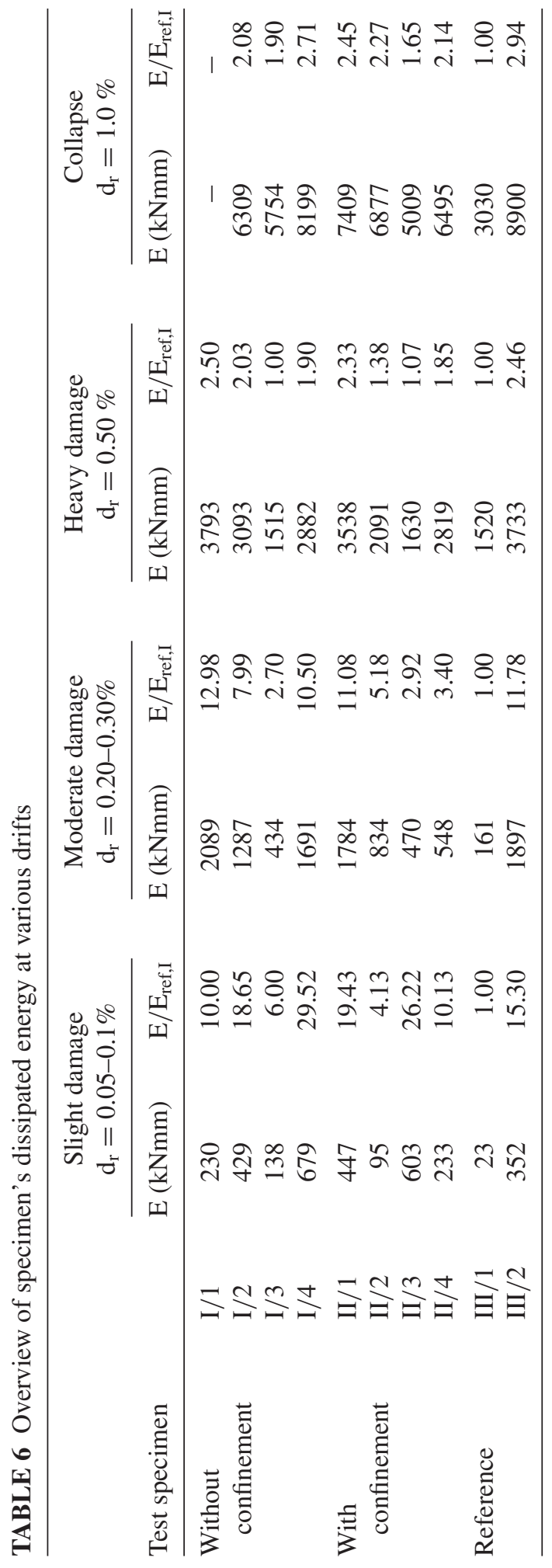




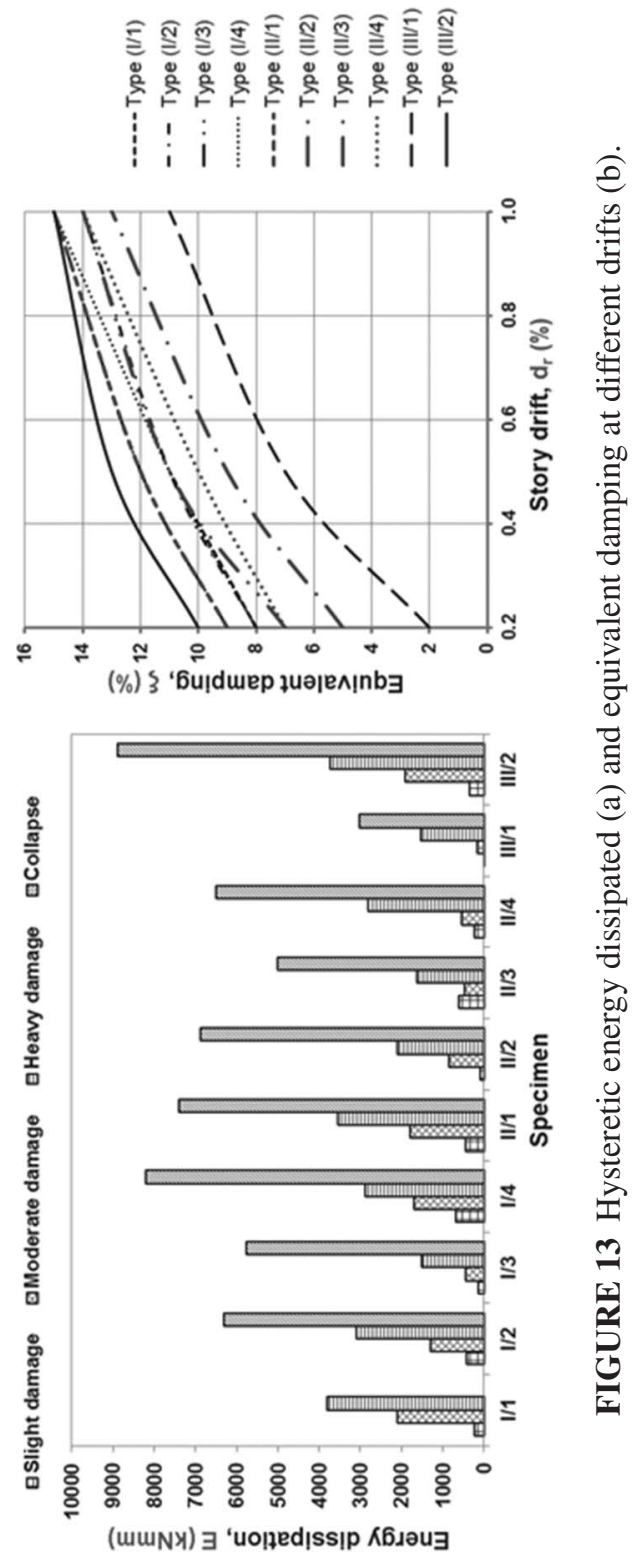




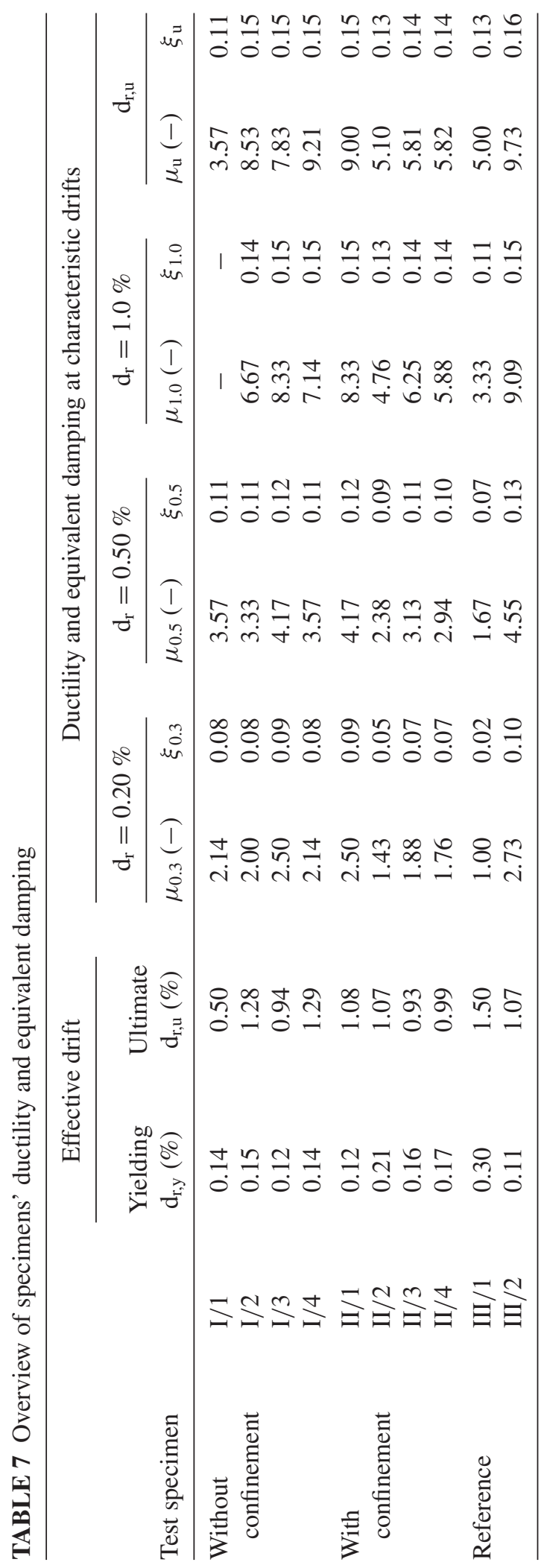




\section{Bilinear Idealization of the Primary Curve}

Obtained resistance envelope curve of the specimens, subjected to constant vertical and cyclic lateral load, was represented by the equivalent bilinear envelope, as given in Tomažević [1999]. The envelope was obtained by equalizing the area above- and below the primary curve for the weaker side of the specimen, as given in Fig. 14. Three limit states were defined: crack limit, determined by the resistance $\mathrm{V}_{\mathrm{cr}}=0.7^{*} \mathrm{~V}_{\mathrm{u}}$ and displacement $\mathrm{d}_{\mathrm{cr}}$; maximum resistance $\mathrm{V}_{\max }$ and displacement $\mathrm{d}_{\mathrm{Vmax}}$; and ultimate resistance, determined by the maximum displacement $d_{u}$ and corresponding resistance $V_{u}$.

The obtained crack $\left(\mathrm{V}_{\mathrm{cr}}\right)$ and ultimate $\left(\mathrm{V}_{\mathrm{u}}\right)$ shear resistance with corresponding drifts are given in Table 8. The effective stiffness $\left(\mathrm{K}_{\mathrm{e}}\right)$ was calculated as the ratio between the resistance and displacement of the system at crack occurrence. As ultimate displacement, $\mathrm{d}_{\mathrm{u}}$, the infill's collapse displacement (case dependent) was recorded. Ductility ratio $(\mu)$ was determined as the ratio between the displacement at which the infill collapsed $\left(d_{u}\right)$ and the yielding displacement $\left(\mathrm{d}_{\mathrm{y}}\right)$. The reinforced-concrete frames remained almost intact at the moment when the infill collapsed. Obtained ductility values were higher than those expected for the confined masonry walls $(\mu=2.5-5.0)$ and the corresponding behavior factors were also higher ( $q=2-3$ for confined masonry) than the values suggested by EN 1998-1 [2004].

\section{Analytical Verification}

The analytical shear resistance was calculated according to Žarnić [1992], Tomažević [1999], and Sorić [2004]. Cracking shear force, corresponding to displacement at the formation of the first significant crack in the wall, was calculated as the fraction of the infill's resistance:

$$
\mathrm{V}_{\mathrm{cr}}=\frac{\mathrm{V}_{\mathrm{Re}}}{3}
$$

The infill's resistance depends on the tensile failure of the masonry, assuming that infill carries the entire lateral load. It is calculated as

$$
\mathrm{V}_{\mathrm{Re}}=\mathrm{C}_{\mathrm{R}} \frac{\mathrm{A}_{\mathrm{m}} \mathrm{f}_{\mathrm{t}}}{\mathrm{C}_{\mathrm{I}} \mathrm{b}}\left\{1+\sqrt{\mathrm{C}_{\mathrm{I}}^{2}\left(1+\frac{\sigma \mathrm{d}}{\mathrm{f}_{\mathrm{t}}}\right)+1}\right\},
$$

where $C_{R}$ - coefficient for the execution quality of masonry $\left(C_{R}=0.9\right), f_{t}-$ tensile strength of the masonry $\left(\mathrm{f}_{\mathrm{t}}=0.2 \mathrm{~N} / \mathrm{mm}^{2}\right)$ used [Penava et al., 2011], $\sigma_{\mathrm{d}}-$ the compression stress induced in the infill due to the interaction forces $\left(\sigma_{\mathrm{d}}=0 \mathrm{~N} / \mathrm{mm}^{2}\right), \mathrm{C}_{\mathrm{I}}-$ interaction coefficient $\left(C_{I}=2.8\right), A_{m}$ - area of the infill's horizontal cross-section, and $b$ - shear stress distribution factor $(b=1.1$ - complete infill, $b=1.5$ - infill with opening).

The ultimate limit state, at which failure of the "framed-wall" occurred, was calculated as

$$
\mathrm{V}_{\mathrm{Ru}}=\mathrm{V}_{\mathrm{Rf}}+\mathrm{V}_{\mathrm{Re}}
$$

where $V_{R f}$ is the resistance of the reinforced-concrete frame without infill.

After the ultimate resistance, the envelope extends horizontally up to drifts when the infill collapsed (1.0\%). Calculated results are presented in Fig. 15 for the cases with (AWO) and without opening (AWOO), along with the measured primary curves. Differences 

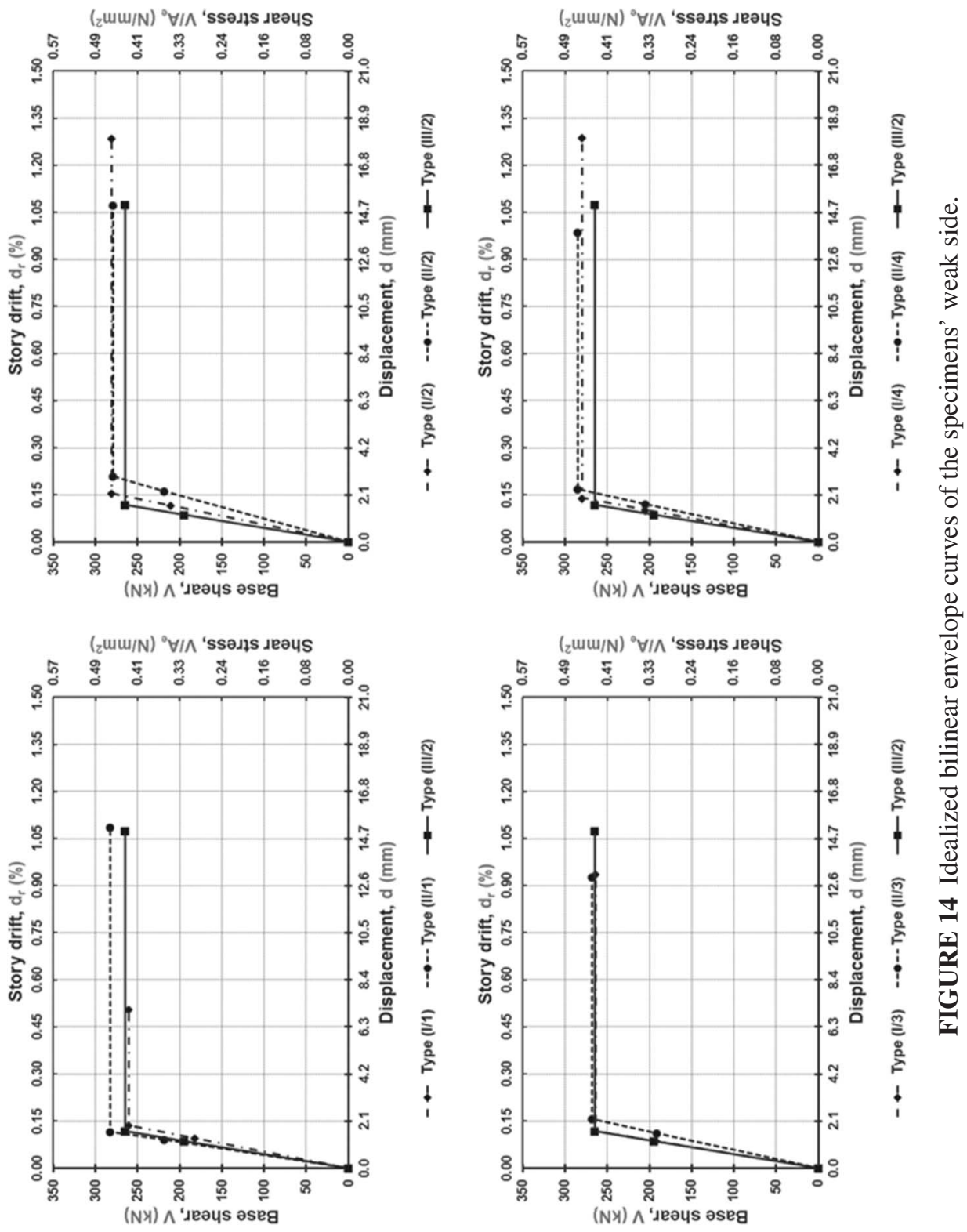

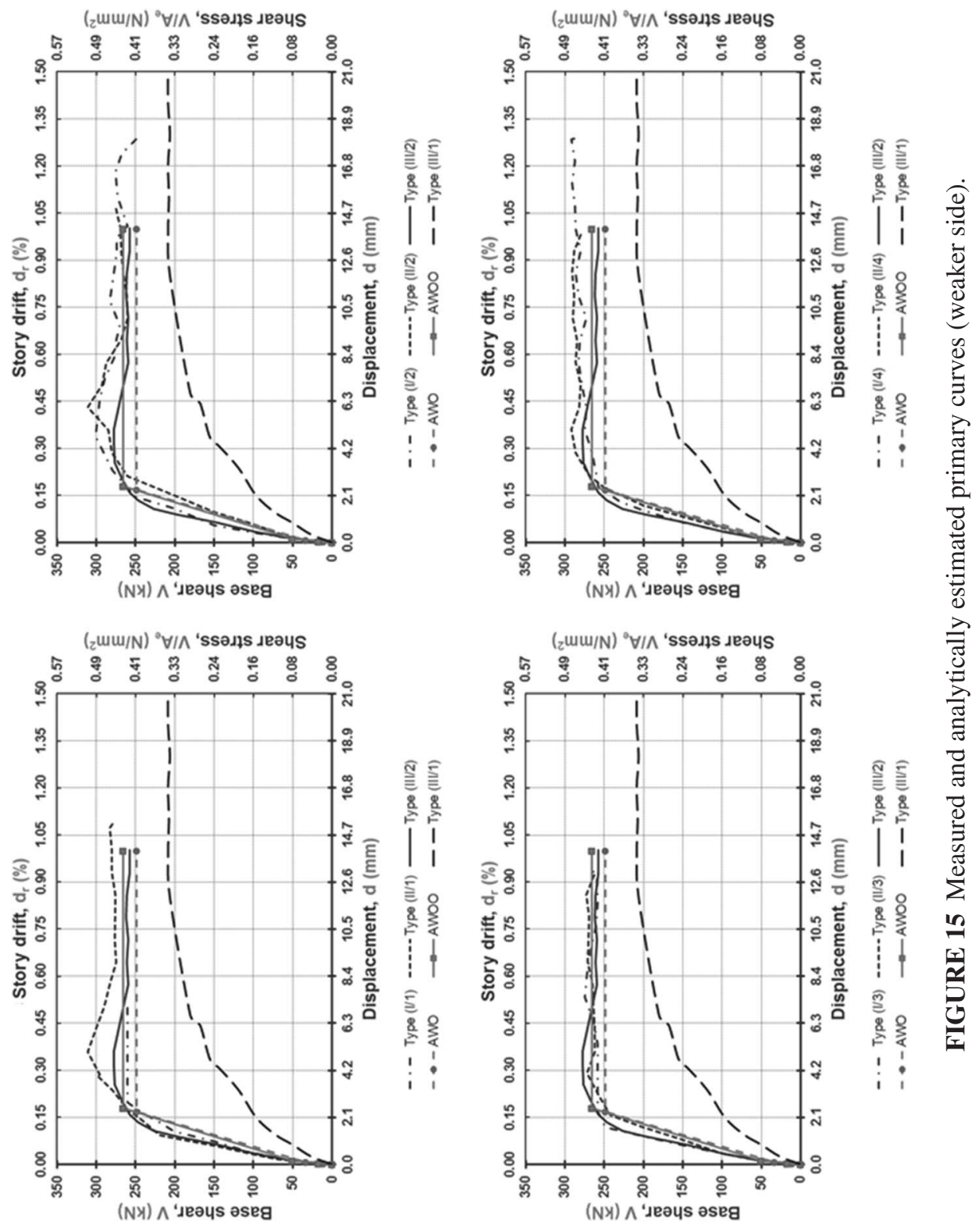


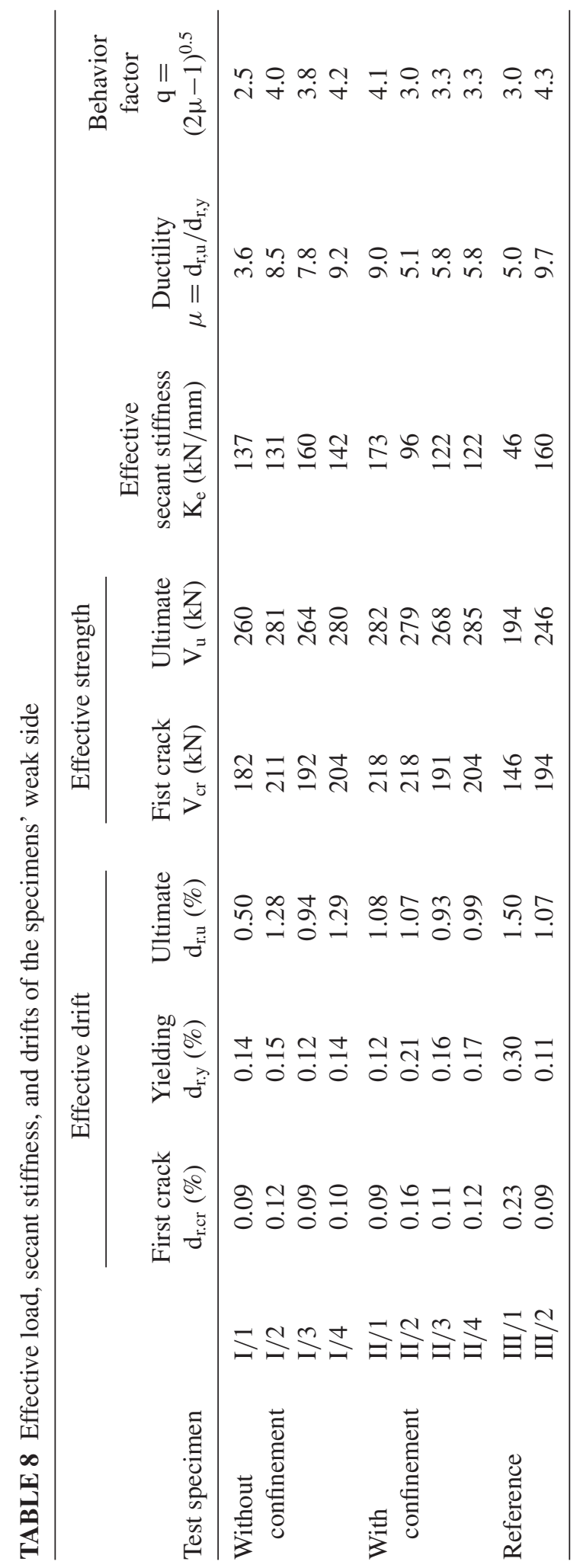


TABLE 9 Comparison of analytical and experimental results

\begin{tabular}{|c|c|c|c|c|c|c|c|c|c|c|c|}
\hline \multirow[b]{2}{*}{ Method } & \multicolumn{4}{|c|}{ Lateral load $(\mathrm{kN})$} & \multicolumn{4}{|c|}{ Drift $(\%)$} & \multicolumn{3}{|c|}{$\begin{array}{c}\text { Secant stiffness } \\
(\mathrm{kN} / \mathrm{mm})\end{array}$} \\
\hline & $\mathrm{V}_{\mathrm{cr}}$ & $\mathrm{V}_{\mathrm{Re}}$ & $\mathrm{V}_{\mathrm{Rf}}$ & $\mathrm{V}_{\mathrm{Ru}}$ & $d_{\text {cr }}$ & $\mathrm{d}_{\mathrm{Re}}$ & $\mathrm{d}_{\mathrm{Rf}}$ & $\mathrm{d}_{\mathrm{Ru}}$ & $\mathrm{K}_{\mathrm{i}}$ & $\mathrm{K}_{\mathrm{e}}$ & $\mathrm{K}_{\mathrm{u}}$ \\
\hline Analytical & 17 & 50 & 215 & 266 & 0.002 & 0.01 & 0.18 & 0.18 & 485 & 343 & 106 \\
\hline Experimental & $\begin{array}{l}200 \\
(166)\end{array}$ & $\begin{array}{l}267 \\
(168)\end{array}$ & 209 & $\begin{array}{l}258 \\
(49)\end{array}$ & 0.10 & 0.22 & 1.0 & 1.0 & 138 & 89 & 17 \\
\hline
\end{tabular}

between the calculated and measured values are presented in Table 9. The measured results given are the shear forces of the framed-wall as system and of the infill only. The latter results were obtained by subtracting the measured shear forces carried by the bare frame from that of the framed-wall.

The cracking $\left(\mathrm{V}_{\mathrm{cr}}\right)$ and yielding load $\left(\mathrm{V}_{\mathrm{Re}}\right)$ correspond to the slight and moderate damage levels. These were seriously underestimated by the analytical approach. In the experiment, yielding of the bare frame occurred at drift of about $1.0 \%$. Its contribution was overestimated at small drifts where the infill carried the major load portion. The calculated contribution of the frame at these drifts presented the major part of the Ultimate load $\left(\mathrm{V}_{\mathrm{Ru}}\right)$ - in the experiments it was different. This could be verified by comparing the primary curves for framed-wall and the bare frame. Drifts calculated by the analytical approach were very low and the stiffness was overestimated for about four times. Opening type, size, position, and presence of the tie-columns had no influence on the calculated shear values.

\section{Influence of the Tie Columns}

Introduction of the tie columns around the opening enabled the preservation of the lateral strength, stiffness and ductility of the specimens with opening as in the fully infilled frame. This was regardless of the opening's type and position. Tie-columns prevented bed-jointsliding of the weakened mortar plane in the specimens with opening (except in the case of the eccentric door, when the tie-column failed in shear). They predetermined vertical masonry piers and increased their height to the infill's height; cracks were distributed on larger infill's area and it remained in-plane.

The failure of all specimens was determined by the pier's failure. The pier formation in the specimens without ties was initiated by bed-joint sliding above and below the opening, while ties constructively pre-determined piers.

The tie-columns should extend over the whole infill's height. They take over the shear forces around opening and should be reinforced with at least four longitudinal bars anchored to the reinforced-concrete by dowels. Good connection between the tie-columns and the infill should be provided either by toothed or dowel connection [EN 1996-1-1, 2005; EN 1998-1, 2004].

\section{Summary and Conclusion}

The influence of openings in infill on the behavior of reinforced-concrete frames infilled with masonry ("framed-wall") was experimentally investigated. Openings were of different types and positions and were executed with and without vertical confining elements around them. Ten specimens produced at a scale of 1:2.5, as practical true models, were tested under constant vertical and quasi-static cyclic lateral loading up to drifts when the infill 
failed. The frames were designed as medium ductility (DCM) bare frames. Masonry wall was produced with hollow-clay units and general purpose mortar. The frame and masonry were connected only by cohesion.

Within the observed drift range from 0-1\%, masonry infill contributed to stiffness, strength and damping. Observed damage levels of the masonry infill were: Slight damage at drifts $\leq 0.1 \%$, Moderate damage at drifts from 0.2 to $0.3 \%$, Heavy damage at drifts from $0.5-0.75 \%$ and Close to collapse damage at drifts $\leq 1.0 \%$. The framed-wall structure had about a threefold higher stiffness than the bare frame, irrespective of the size and position of the opening. Stiffness contribution decreased with increase of the drift and was negligible for drifts of about $0.75 \%$ for infill without ties and $1 \%$ for infill with ties. Presence of tiecolumns contributed to strength and stiffness of framed-walls at higher displacements. For lateral strength and stiffness it was better to have one large pier (eccentric opening) than two smaller ones (centric opening). Door opening was less favorable than window opening, because of the early loss of stability of masonry without ties.

Openings in the infill influenced the failure mode. In the specimens without ties (Group I) a sequence of failure modes determined by the opening's geometry occurred. Diagonal cracks, mainly on the piers, were directly connected with the failure mode. Additional corner crushing at the opening's corners occurred. In specimens with ties (Group II), similar failure modes occurred irrespective of the opening's type and position. Ties influenced the failure mode and prolonged the infill's contribution to strength and stiffness.

Stiffness, lateral strength, and hysteretic damping of the framed-walls, with and without openings, were similar. Infill contributed to the stiffness, strength and hysteretic damping of the framed-wall structures, within the observed drift range. Obtained ductility values and behavior factors were higher than those for confined masonry walls. The reinforced-concrete frame remained almost intact when the infill was close to collapse, and the infill's contribution could be deemed as positive by enhancing the overall structural performance level. Dangers that could arise from the soft story mechanism, which can localize deformations within one floor, also have to be taken into account.

The analytical expressions presented that are used for infilled frames poorly represented the behavior observed in experiments. They underestimated the infill's contribution to strength and stiffness of the framed-walls at small drift ranges and overestimated that of the bare frame. Other masonry panel solutions or different connection details between the infill and frame could enhance the possibility of fully exploiting masonry infill in the design of new "framed-wall" buildings. Shear contribution of the infill as well as overall structural behavior would be improved if some shear transfer mechanisms between the masonry and concrete were used. Masonry infill, with or without opening, improved the frame's behavior and provided shift in the overall damage control ranges from the life safety to the operational building performance level.

\section{Acknowledgments}

The research presented in this article is a part of the research project "Seismic Design of Infilled-Frames" supported by the Ministry of Science, Education and Sport of the Republic of Croatia, and its support is gratefully acknowledged.

\section{References}

Akin, L. A. [2006] "Behaviour of reinforced concrete frames with masonry infills in seismic regions," Purdue University, West Lafayette, Indiana. 
Aschheim, M. A. [2000] "Performance of buildings, in 1999 Kocaeli, Turkey, Earthquake Reconnaissance Report," Earthquake Spectra 16, 237-279.

Crisafulli, J. [1997] "Seismic behaviour of reinforced concrete structures with masonry infills," University of Canterbury, Christchurch, New Zealand.

DEWE-BOOK [2010] "DEWE-BOOK," Retrieved from http://www.dewetron.nl/book/index.htm.

DEWESoft v.6.6.7 [2010] “DEWESoft v.6.6.7," Retrieved from http://www.dewesoft.com/ download.

EN 1015-11:1999/A1 [2006] "Methods of test for mortar for masonry - Part 11: Determination of flexural and compressive strength of hardened mortar," European Committee for Standardization, Brussels.

EN 1052-1 [1998] "Methods of test for masonry - Part 1: Determination of compressive strength," European Committee for Standardization, Brussels.

EN 1052-3 [2002] "Methods of test for masonry - Part 3: Determination of initial shear strength," European Committee for Standardization, Brussels.

EN 12390-3 [2009] "Testing hardened concrete - Part 3: Compressive strength of test specimens," European Committee for Standardization, Brussels.

EN 1992-1-1 [2004] "Eurocode 2: Design of concrete structures - Part 1-1: General rules and rules for buildings," European Committee for Standardization, Brussels.

EN 1996-1-1 [2005] "Eurocode 6 - Design of masonry structures - Part 1-1: General rules for reinforced and unreinforced masonry structures," European Committee for Standardization, Brussels.

EN 1998-1 [2004] "Eurocode 8: Design of structures for earthquake resistance - Part 1: General rules, seismic actions and rules for buildings," European Committee for Standardization, Brussels.

EN 771-1 [2003] "Specifications for masonry units - Part 1: Clay masonry units," European Committee for Standardization, Brussels.

EN 772-1 [2000] "Methods of test for masonry units - Part 1: Determination of compressive strength," European Committee for Standardization, Brussels.

EN 772-13 [2000] "Methods of test for masonry units - Part 13: Determination of net and gross dry density of masonry units (except for natural stone)," European Committee for Standardization, Brussels.

EN 772-16:2000/A1 [2004] "Methods of test for masonry units - Part 16: Determination of dimensions," European Committee for Standardization, Brussels.

EN 772-3 [1998] "Methods of test for masonry units - Part 3: Determination of net volume and percentage of voids of clay masonry units by hydrostatic weighing," European Committee for Standardization, Brussels.

Fardis, M. N. and Panagiotakos, T. B. [1997] "Seismic design and response of bare and masonryinfilled reinforced concrete buildings. Part II: infilled structures," Journal of Earthquake Engineering 1(3), 475-503.

FEMA 273 [1997] "NEHRP guidelines for the seismic rehabilitation of buildings," Washington, D.C.

FEMA 274 [1997] "NEHRP commentary on the guidelines for the seismic rehabilitation of buildings," Washington, D.C.

FEMA 306 [1998] "Evaluation of earthquake damaged concrete and masonry wall buildings," Washington, D.C.

FEMA 356 [2000] "Prestandard and commentary for the seismic rehabilitation of buildings," Washington, D.C.

FEMA 461 [2007] "Interim testing protocols for determining the seismic performance characteristics of structural and non-structural components," Washington, D.C.

Gulkan, P. and Sozen, M. A. [1974] "Inelastic response of reinforced concrete structures to earthquake motions," American Concrete Institute Journal 71(12), 604-610.

Hassan, A. F. and Sozen, M. A. [1997] "Seismic vulnerability assessment of low-rise buildings in regions with infrequent earthquakes," ACI Structural Journal 94(1), 31-39.

Henderson, R. C., Fricke, K. E., Jones, W. D., Beavers, J. E., and Bennett, R. M. [2002] "Summary of large- and small-scale unreinforced masonry test program," Technical Report. Y-12 National Security Complex, Oak Ridge, Tennessee. 
Kakaletsis, D. J. and Karayannis, C. G. [2007] "Experimental investigation of infilled r/c frames with eccentric openings," Structural Engineering and Mechanics 26(3), 231-250.

Kakaletsis, D. J. and Karayannis, C. G. [2009] "Experimental investigation of infilled reinforced concrete frames with openings," ACI Structural Journal 106(2), 1-10.

Kakaletsis, D. J. and Karayannis, C. G. [2008] "Influence of masonry strength and openings on infilled R/C frames under cycling loading," Journal of Earthquake Engineering 12(2), 197-221.

Kalman, T. and Sigmund, V. [2008] "Prediction of behavior of the infilled R/C frames under lateral loads," in Modeling of Structures, Mostar, Bosnia and Herzegovina, pp. 237-250.

Kyriakides, M. A. and Billington, S. L. [2008] "Seismic retrofit of masonry-infilled non-ductile reinforced concrete frames using sprayable ductile fiber-reinforced cementitious composites," 14 WCEE, Beijing, China.

Matošević, Đ., Zovkić, J., and Sigmund, V. [2006] "Experimental testing of masonry and masonry piers," Croatian Society of Mechanics, 6th ICCSM Proceedings, Zagreb, Croatia, pp. 1-8.

Mehrabi, A. B. and Shing, P. B. [1997] "Finite element modeling of masonry-infilled RC frames," Journal of Structural Engineering 5(123), 604-613.

Murty, C. V. R. [2006] "At risk: the seismic performance of reinforced concrete frames with masonry infill walls," Earthquake Engineering Research Institute, Oakland, California.

Penava, D., Radić, I., Gazić, G., and Sigmund, V. [2011] "Mechanical properties of masonry as required for the seismic resistance verification," Technical Gazette 18(2), 273-280.

Sezen, H., Flrat, G. Y., and Sozen, M. A [2003] "Investigation of the performance of monumental structures during the 1999 Kocaeli and Düzce earthquakes," Fifth National Conference on Earthquake Engineering, Istanbul, Turkey.

Sorić, Z. [2004] Zidane konstrukcije I, 2nd ed., Zagreb, Croatia.

Stafford-Smith, B. S. [1966] "Behavior of square infilled frames," ASCE 92(1), 381-403.

Tomažević, M. [1999] Earthquake-resistant Design of Masonry Buildings, Imperial College Press, London.

Zovkic, J., Sigmund, V., and Guljas, I. [2012] "Cyclic testing of a single bay reinforced concrete frames with various types of masonry infill," Earthquake Engineering \& Structural Dynamics 42(8), 1131-1149.

Žarnić, R. [1992] "Neelastični odziv armiranobetonskih okvirov z zidanimi polnili na potresno obtežbo,” FGG, Univerza v Ljubljani, Ljubljana, Slovenia. 